\title{
HABITAT URBANIZATION AND ITS EFFECTS ON BIRDS
}

\author{
GÁbor Seress and ANDrás LiKer \\ Department of Limnology, University of Pannonia, H-8200 Veszprém, Pf. 158, Hungary \\ E-mails: seressg@almos.uni-pannon.hu, andras.liker@gmail.com
}

By transforming landscapes, human activity creates new types of habitats with altered environmental characteristics that never existed before. As the process of habitat urbanization bears impact on more and more natural habitats, it is essential for us to understand the changes we bring forth in the ecological forces shaping urban animal communities. Birds are perhaps the most frequently studied model organisms by urban ecologists. It is a well known general pattern that urban avian communities have typically reduced species richness, while the density of a few successful species is often higher in cities than in adjacent more natural habitats. But it is less understood which mechanisms generate and uphold these community-level changes. In this review we discuss the most important components of the urban environment influencing birds' physiology, behaviour or morphology, and compile several recent studies to illustrate their effects. To understand urban food webs we also review the results of bottom-up and top-down approach which suggest that altered food availability and predation may play key roles in forming recent urban bird communities. We encourage future research to focus more on experimental, manipulative studies, that would help us not just to realize general patterns but shed more light on the mechanisms, the underlying processes prompting changes in urban bird communities.

Key words: urban ecology, species richness, resources, predation, bottom-up effect, topdown effect.

\section{URBANIZATION AS A WORLDWIDE PHENOMENON}

Our planet is urbanizing rapidly as Earth's urban-dwelling human population is growing by one million per week nowadays. The pace of urbanization is excellently illustrated by the facts that while in $1950 \mathrm{ca} .30 \%$ of our planet's human population lived in cities, this ratio has reached the $50 \%$ in 2008 and continuously growing ever since (UN-НавітAт 2012). This trend has been especially dramatic in the developing countries of Africa, Asia and Latin America in the last decades (LEE 2007). It is an inevitable consequence that with increasing number and extension of human settlements, the environmental pressures called forth by this process are also become more and more severe. Urbanized landscapes have seriously altered energy flux, nutrient cycles, hydrology and heat balance, highly elevated pollution levels (e.g. Coluins et al. 2000). They are also examples of extreme anthropogenic landscape transformations, with the great proportion of artificial and impermeable surfaces, the altered and maintained flora, high human densities and vast amount of garbage having significant impacts on biodiversity and ecosystems (Ріскетt et al. 2011). It is 
undoubtful that urban landscapes differ from natural ones in several environmental features which in turn determine the properties of both animal and plant communities trying to persist in these unique habitats.

In this review, first we discuss the most important types of environmental changes in urban habitats. Next, we consider the outcome of these changes as reflected in avian species diversity and composition in urban areas. Then we discuss how the top-down and bottom-up forces in urban food webs can influence bird populations of the cities. Finally we delineate some factors limiting our current understanding and also propose some research directions that would help us to gain more insight into how these crucial ecological factors change along an urbanization gradient and what impacts do these changes yield in urban bird communities.

\section{URBANIZATION: EFFECTS ON ENVIRONMENTAL COMPONENTS}

Perhaps the most well know feature of the urbanized environments is their substantially altered local meteorological conditions (PARLOw 2011). For example, precipitation is often enhanced in cities due to the higher concentration of particulates serve as condensation nuclei (РіскETT et al. 2001). The phenomenon called urban heat island effect is one of the best documented climatic feature of cities, referring to the higher temperatures of urban areas compared to their surroundings (Collins et al. 2000, Kalnay \& Cei 2003). The difference between urban and non-urban temperatures can be several degrees on average and especially noticeable after sunset when the absorbed heat during daytime is reemitted (Pickett et al. 2011). Animal and plant populations may respond to the higher urban temperature, for example, by earlier blooming dates and prolonged vegetation growth period, in which phenomena the reduced risk of springtime frost in cities plays a remarkable role (e.g. reviewed by NeIL \& Wu (2006)). The altered vegetation phenologies (e.g. earlier bud burst, flowering, fruiting) affect the life cycles of insects which, in turn affect the arthropod food availability for bird species. If birds cannot respond as quickly to changes in spring phenology as their invertebrate prey, then the earlier appearance of arthropods may decouple the interactions in predatorprey relationships, i.e. by causing asynchrony between the peak abundance of phytophagous insects (e.g. caterpillars) and the timing of breeding of insectivorous birds (e.g. Penuelas \& Filella 2001, Visser et al. 2006). On the other hand, however, warmer climate in the city may also influence birds' overwinter survival, leading to increased breeding populations (e.g. CHACE \& WALSH 2004). However, to test the role of milder climate in itself, separated from other features of habitat-urbanization (e.g. from the influence of food availability), is challenging. 
Urban areas are also sources of many types of chemical pollution, with concentrations several times higher than the global average. Air, soil and water pollution (due to emissions from industry, traffic and heating, or nutrient loads to water bodies) cause changes in biogeochemical and nutrient cycles and primary production (e.g. GRIMm et al. 2008); however, pollutants' exact mode of action are still not well understood (Ріскетт et al. 2011). Their effects may expand well beyond city boundaries and once entered to the food chain, they can be detrimental for a wide range of organisms, including birds (e.g. Eeva et al. 1998, 2003). Small, insectivorous songbirds are good indicators of chemical pollution, since they occupy high trophic levels and have high metabolic rate. In urban areas enhanced levels of bioaccumulation of heavy metals has already been demonstrated in many common bird species, e.g. in the House Sparrow Passer domesticus (Swaileh \& Sansur 2006, KeкKоnen 2011, Bicheт 2013), the House Wren Troglodytes aedon or the American Robin Turdus migratorius (HoFER et al. 2010). The detrimental, synergistic effects of such pollutants on birds' physiology is also documented by several studies (e.g. Outridge \& Scheuhammer 1993, Eeva \& Lehikoinen 1996) and it also known that young individuals are more sensitive in general (SCHEUHAMmeR 1987), suffering from higher mortality, reduced body mass and condition (e.g. JANSSENS et al. 2003). Heavy metal pollution may pose both direct and indirect detrimental effects on birds' reproductive success. To assess their relative importance, a recent study (Eeva et al. 2014) manipulated the dietary lead (Pb) levels at Great Tit Parus major nests, and compared these nestlings' physiological, biometrical and plumage traits to those of the nestlings living in a heavily polluted area (near a copper smelter). Despite of the similar exposure of lead in the treatment group and in the birds of the highly polluted area, chicks of the latter exhibited lower survival, decreased size and also the signs of inferior health state, compared to the treatment groups. This result underlines the potential indirect effects pollutants e.g. by affecting the arthropod fauna serving as food for the birds.

Ecological light pollution is another characteristic disturbance related to urban settlements which is caused by the high number of artificial light sources used in the cities. It has complex and subtle effects mainly on animal behaviour via affecting animals' orientation, migration, foraging, reproduction and communication (reviewed by LongCORE \& Rich 2004). It may also result in forming new interactions between competitors (e.g. Petren \& Case 1996) or predators and their preys (PERRY \& FISHER 2006) that would not meet normally. Artificial nightlighting has demonstrable effects on a wide range of animal taxa from flying insects (EISENBEIS \& HäNEL 2009) to several vertebrate groups, including birds (GAUTHREAUX \& BELSER 2006). In birds, especially migrant species are susceptible to light pollution as many migrate during 
night, and hypothesized to use light sources as visual references instead of natural cues on the horizon, especially on nights with heavy clouds and fog (Gauthreaux \& Belser 2006). Once being attracted, they can either become trapped and/or die from collision or exhaustion, and may additionally suffer from other consequences, e.g. reduced energy stores or delayed arrival at wintering or breeding areas. As light is supposed to initiate singing behaviour in birds, artificial night time illumination should also affect territorial and courtship behaviour (reviewed by Gauthreaux \& Belser 2006). In line with this, males of several bird species has been demonstrated to start their dawn choruses earlier in sites with more pronounced light pollution compared to their conspecifics of darker territories (Miller 2006, Kempenaers et al. 2010). A recent study on captive Eurasian Blackbird Turdus merula found that, when exposed to low light levels during nights, individuals started to moult and developed their reproductive system earlier compared to birds kept under dark night conditions, similar to forest nights (Dominoni et al. 2013a). The underlying physiological mechanisms were investigated on urban- and city-dweller Blackbird kept under constant conditions (Dominoni et al. 2013b). It turned out that forest and urban birds differed both in their chronotype and circadian clock, as the urban birds had longer daily activity (i.e. woke up before dawn) and shorter circadian period length, whereas forest birds' timing of starting and ending the day was more closely related to the natural twilight. Russ et al. (2014) also demonstrated that urban Blackbird exposed to higher levels of night lighting forage longer after dusk, a difference especially notable in early spring when daylight hours are short. However, the authors did not find any positive correlation between light intensity and body condition, suggesting that birds might not profit from the extended foraging time (but they may have more time for mating or other activities during day time). From all of these studies it seems clear, that artificial light pollution has a substantial effect on behaviour and modifies the endogenous circadian rhythmicity of urban birds.

Anthropogenic noise pollution refers to the altered acoustic environment of cities and transportation networks. It has impacts on animal communication systems and behaviour by masking acoustic signals related to territorial defence, mate attraction, alarm calls, pair-bond maintaining calls, and begging calls of nestlings (WARREN et al. 2006). For example, in European robin Erithacus rubecula it has been experimentally demonstrated that noise level influences both spatial distribution of males (they avoid noise-emitting sources) and their singing behaviour (McLaughlin \& Kunc 2013). The assumption that elevated noise levels affect birds' breeding success negatively has gained support on a few species so far. For example, a study conducted in the proximity of a highway showed that Great tits breeding in noisier areas had smaller 
clutches and raised fewer chicks independent of clutch size (HALFwerk et al. 2011). Other studies found that males of noisy territories are often lower quality, younger ones that are less successful in attracting mates, presumably because females either avoid these sites or the song of these males are masked, or both (e.g. НАвIB et al. 2007, Gross et al. 2010). The latter phenomenon can be a handicap for males owning noisier territories, since song repertoire and characteristics are known to be important cues for females to assess a potential partner's quality. A study of House Sparrows suggests acoustic interference by noise in parent-offspring communication: SCHROEDER et al. (2012) has found that parents breeding in chronic noise reach lower reproductive success compared to parents of control areas - supposedly because elevated noise masks parent-offspring vocal communication, e.g. begging calls of nestlings. Noise pollution may also cause physiological stress, or affect other aspects of behaviour, e.g. it may interfere with sounds playing important roles in predator-prey interactions (BARBER et al. 2009). For example, in elevated background noise Chaffinches Fringilla coelebs increase their vigilance and reduce their pecking rate during foraging (QuinN et al. 2006), and in Tree Swallows Tachycineta bicolor the experimentally elevated static noise reduced nestlings' ability to respond parental alarm calls properly (MCINTYRE 2013). Since anthropogenic noise is concentrated mainly at low frequencies (WARREN et al. 2006), bird species using high-frequency songs (i.e. masked less by urban noise) supposed to be in selective advantage compared to species with lowerfrequency songs, proposing the idea that the former could be preadapted to inhabit urban environments. This hypothesis has gained some support from within-genera comparisons in more than a hundred avian genera (HU \& CARDoso 2009) outlining the role that noise pollution may play in the success or failure of certain species in urban environments. However, it seems that at least some bird species are able to compensate for elevated noise levels by altering their singing characteristics e.g. amplitude or frequency, as it was found in Common Nightingale Luscinia megarhynchos (Brumm 2004), Great Tits (Slabbekoorn \& Peet 2003, Slabbekoorn \& van Boer-Visser 2006), Song Sparrows Melospiza melodia (Wood \& Yezerinac 2006) or Grey-shrikethrush Colluricincla harmonica (PARRIS \& SCHNEIDER 2009), due to either behavioural plasticity or evolutionary adaptation. Interestingly, noise pollution may also offer an alternative explanation to the phenomenon of nocturnal singing of diurnal birds in cities: this behaviour could be an adaptive response by which birds try to avoid daytime acoustic interference while singing (Fuller et al. 2007).

Roads are prominent features of urbanized landscapes that are sources of various traffic-related pollutants, alter hydrological systems (Coffin 2007) and also increase collision mortality (ANDREws et al. 2008). Road avoidance 
in animals, especially due to traffic noise is a well known phenomenon. In their meta-analysis, Benítez-Lopez et al. (2010) found a general decrease in bird population densities with the increased proximity of roads. However, the species abundance of Accipitriformes and Falconiformes were higher nearby the infrastructure, probably because of the extra foraging opportunities that roadkill carcasses offer. This study also proved that road-effect zones may expand up to a kilometer in most of the studied bird species, and this effect is more prominent in open areas compared to forest habitats. Interestingly, birds also show behavioural adaptations to road traffic, e.g. Legagneux and Ducatez (2013) found that individuals of common European species adjusted their flight initiation distance (an indicator of escape propensity) to the speed limits of roads, with earlier escape (longer flight initiation distances) on roads with higher speed limits.

Perhaps the most characteristic components of urbanized landscapes are buildings. Building-covered patches are unsuitable areas for many birds because they cannot use these as foraging or breeding sites (but see below for exceptions). In addition, buildings are usually associated with increased human activity, pets, pollution, elevated noise and light levels, reduced vegetation, thus, might be avoided by species susceptible to disturbance. However, more tolerant species may gain benefits from their presence (Miller et al. 2001). For example, the proximity of buildings may serve as a thermal shelter for overwintering arthropods (reviewed by RAupp et al. 2010) and certain bird species preferentially roost or breed in houses. Collision mortality in birds is also highly increased by the presence of buildings. Long distant migrants during their annual spring and fall routes are especially vulnerable to such risks; however, a recent study on North-American birds failed to find positive correlation between collision mortality and long-term population trends (ARNOLD \& ZINK 2011). Last but not least, with increasing building density the surface covered by vegetation is necessarily reduced and spatially more heterogeneous, adversely affecting the distribution, abundance and species richness of many native animal taxa. Reduced vegetation is also one of the major factors responsible for urban heat islands (see above), as vegetation cover decreases the amount of absorbed solar radiation, and cools air temperature by evapotranspiration (PicKeTt et al. 2011).

The above is not a complete list of the altered environmental components affecting wildlife in urban areas, though it demonstrates the complex, wideranging effects of urbanization on habitat characteristics (Table 1). However, while some of these abiotic factors seem to be unique to cities (e.g. heat islands, various pollution types, severe disturbances) they can also be found far from human dominated habitats. Hence, urban environment is not unequalled because of its novel types of disturbances, but mostly the combination, intensity and extent of these environmental features make it special (FAETH et al. 2011). 
Table 1. Common features of urban ecosystems mediated by human activities and examples of their positive and negative impacts on birds.

\begin{tabular}{|c|c|c|}
\hline \multirow{2}{*}{$\begin{array}{l}\text { Features of ur- } \\
\text { banized habitats }\end{array}$} & \multicolumn{2}{|c|}{ Impacts on birds } \\
\hline & Positive & Negative \\
\hline $\begin{array}{l}\text { Increased tem- } \\
\text { perature (heat } \\
\text { island effect) }\end{array}$ & $\begin{array}{l}\text { - Prolonged vegetation pe- } \\
\text { riod enables extended breeding } \\
\text { season (e.g. multiple broods per } \\
\text { year). } \\
\text { - Increased overwinter survival } \\
\text { and higher post-winter body } \\
\text { condition. } \\
\text { - Reduced annual fluctuations in } \\
\text { population size. }\end{array}$ & $\begin{array}{l}\text { - Altered phenology leading to } \\
\text { increased asynchrony between } \\
\text { trophic levels. }\end{array}$ \\
\hline $\begin{array}{l}\text { Increased chemi- } \\
\text { cal pollution }\end{array}$ & & $\begin{array}{l}\text { - Bioaccumulation of pollutants } \\
\text { affects birds' physiology leading } \\
\text { to reduced body condition. } \\
\text { - Reduced arthropod fauna } \\
\text { affects insectivorous birds' diet } \\
\text { leading to their decreased breed- } \\
\text { ing success. }\end{array}$ \\
\hline $\begin{array}{l}\text { Increased light } \\
\text { pollution }\end{array}$ & - Longer period of activity. & - Altered behaviour. \\
\hline $\begin{array}{l}\text { Increased noise } \\
\text { pollution }\end{array}$ & & $\begin{array}{l}\text { - Increased stress. } \\
\text { - Interference in communication } \\
\text { and predator-prey interactions. } \\
\text { - Altered behaviour. }\end{array}$ \\
\hline Increased traffic & & $\begin{array}{l}\text { - Increased risk of collision } \\
\text { mortality. } \\
\text { - Increased pollution and distur- } \\
\text { bance leads to decreased body } \\
\text { condition. }\end{array}$ \\
\hline $\begin{array}{l}\text { Landcover } \\
\text { change: in- } \\
\text { creased area of } \\
\text { impermeable } \\
\text { surfaces }\end{array}$ & & $\begin{array}{l}\text { - Decreased vegetation cover } \\
\text { leading to reduced food avail- } \\
\text { ability (granivorous and insec- } \\
\text { tivorous birds). } \\
\text { - Decreased nest site availability } \\
\text { for species nesting in foliage. }\end{array}$ \\
\hline $\begin{array}{l}\text { Landcover } \\
\text { change: de- } \\
\text { creased veg- } \\
\text { etation cover, } \\
\text { increased pro- } \\
\text { portion of exotic } \\
\text { plants. }\end{array}$ & & $\begin{array}{l}\text { - Reduced natural food availabil- } \\
\text { ity (granivorous and insectivo- } \\
\text { rous birds). } \\
\text { - Decreased nest site availability } \\
\text { for species nesting in foliage. }\end{array}$ \\
\hline
\end{tabular}


Table 1 (continued)

\begin{tabular}{|c|c|c|}
\hline \multirow{2}{*}{$\begin{array}{l}\text { Features of ur- } \\
\text { banized habitats }\end{array}$} & \multicolumn{2}{|c|}{ Impacts on birds } \\
\hline & Positive & Negative \\
\hline $\begin{array}{l}\text { Artificial nest- } \\
\text { sites (buildings, } \\
\text { nest-boxes) }\end{array}$ & $\begin{array}{l}\text { - Increased nest site availability } \\
\text { for certain species. }\end{array}$ & \\
\hline $\begin{array}{l}\text { Altered food } \\
\text { and nutrient } \\
\text { availability }\end{array}$ & $\begin{array}{l}\text { - Increased survival (omnivo- } \\
\text { rous bird species). } \\
\text { - Increased body condition of } \\
\text { adults (omnivorous bird species). } \\
\text { - Reduced annual fluctuations in } \\
\text { population size. }\end{array}$ & $\begin{array}{l}\text { - Decreased body condition and } \\
\text { survival of nestlings (insectivo- } \\
\text { rous birds). } \\
\text { - Increased reliance on anthropo- } \\
\text { genic food sources. } \\
\text { - Increased risk of disease trans- } \\
\text { mission on bird feeders. }\end{array}$ \\
\hline $\begin{array}{l}\text { Altered preda- } \\
\text { tion pressure }\end{array}$ & $\begin{array}{l}\text { - Increased or decreased preda- } \\
\text { tion risk of nests and adults } \\
\text { (location specific). }\end{array}$ & $\begin{array}{l}\text { - Increased or decreased preda- } \\
\text { tion risk of nests and adults } \\
\text { (location specific). }\end{array}$ \\
\hline $\begin{array}{l}\text { Introduction of } \\
\text { exotic, ubiqui- } \\
\text { tous species }\end{array}$ & & $\begin{array}{l}\text { - Increased competition for na- } \\
\text { tive species. } \\
\text { - Biotic homogenization. }\end{array}$ \\
\hline
\end{tabular}

\section{EFFECTS OF URBANIZATION ON AVIAN BIODIVERSITY AND SPECIES COMPOSITION}

As we show above, habitat urbanization has both adverse and beneficial effects on bird populations, and the collective and often synergistic impacts of these will determine which birds can persist, colonize, or become extinct in urban habitats. In general, the many detrimental aspects of urban environments often result in decreased species diversity. Birds usually exhibit lower species richness and evenness in urban regions compared to more natural areas, with the lowest diversities documented in urban core areas (McKINNEY 2002, 2008). However, the decrease in avian biodiversity with increasing urbanization is not strictly monotonic, as avian species richness often tends to peak in the suburbs, i.e. at intermediate levels of urbanization (BLAIR 1996, Marzluff 2001, 2005, Chace \& Walsh 2006, LepczyK et al. 2008). This pattern may be explained by the intermediate disturbance hypothesis (ConNell 1978) which predicts that areas with moderate levels of disturbance (e.g. human influences) will harbour higher species diversity than areas with higher or lower frequency and/or degree of disturbance, because the regular, low-scale disturbances promote landscape heterogeneity, create novel communities (because different habitats occur alongside to each other), and also prevent the strongest competitors rising to competitive exclusion. Additionally, in these rural to urban transition zones species responding positively and negatively 
to urbanization may co-occur. To our knowledge, however, it has not been tested exactly which characteristics or processes of suburban areas promote local species diversity.

Besides diversity, urbanization also influences species composition of the avifauna. According to the terminology of BlaIR (1996), bird species of urban areas can be categorized as urban avoiders, urban adapters and urban exploiters, differing e.g. in the degree to which they can tolerate disturbance and utilize and rely on human-provided resources (McKInNEY 2002). Typical urban avoiders are often long-term migrants, habitat specialists (e.g. exclusively feeding on arthropods), or species that are very sensitive to human-related disturbances (e.g. large raptors), because, for example they are nesting on the ground. These birds are mostly native in a community and can be found in relatively undisturbed habitats (covered mainly of native vegetation) outside of cities. Urban avoiders are the most adversely affected by urbanization, resulting in their abundance to be the lowest in urban areas. Urban adapters are often edge species, residing in areas with intermediate levels of disturbance (e.g. suburbs), and besides natural resources they facultatively utilize a remarkable proportion of human provided resources, e.g. food from garbage or bird feeders. Cavity or shrub nesters and omnivore species are typical in this category, such as members of families Corvidae or Paridae (e.g. CROCI et al. 2008), or some ground feeding finch species. Similarly, several gull species are also successfully established colonies in coastal cities, nesting on roof-tops (e.g. Rоск 2005). Urban adapters include both native and non-native species, and they tend to be dominant in the rural to urban transition areas (at intermediate development), where land-use is the most heterogeneous. The group with highest urban abundance, the urban exploiters (or synurbic species, Francis \& Снаswicк 2012) can be found in the most urbanized areas, where native habitats are scarce and human-altered conditions are predominant. These species not only tolerate but prefer urbanized areas, proven by that their populations typically reach higher densities in urban compared to more natural habitats. It is important to keep in mind however, that a species can labelled as synurbic in one location, but not in other - therefore it is more appropriate to speak of synurbic populations, rather than entire species, except if a species is synurbic across all of its range (Francis \& CHAswick 2012). The communities of urban exploiters are frequently characterized by a few prevailing and often alien species (e.g. van RensBurg et al. 2009), and by few native ones; furthermore, their diversity and abundance is usually not dependent upon natural vegetation (reviewed by McKinney 2006). Synurbic species not only exploit but often have become dependent on sources provided by humans (Sноснат et al. 2006), e.g. the Feral Pigeon Columba livia, House Sparrow or European Starling Sturnus vulgaris can be termed to be worldwidely synurbic. Other species, like the House Crow Corvus splendens, Common Myna Acridotheres tristis in Australia 
or India, the Blackbird in many parts of Europe, the House Finch Haemorhous mexicanus in North America are also good examples of this category. Compared to urban adapters which are often early successional species from more natural habitats adjacent to cities, exploiters are well adapted to human-dominated landscapes, often sharing a long common history with humans (e.g. the House Sparrow, ERicson 1997, SAETRE et al. 2012).

Further general aspects of species composition are that the proportion of exotic species increases toward heavily urbanized areas (MARZLUfF 2001, LePCZYK et al. 2008, vAN RENSBURG et al. 2009) and that bird communities of highly urbanized areas are structurally simpler compared to those of more natural areas (i.e. in relatively simple food webs and reduced ecosystem complexity offer reduced type of niches to similar species; McKinney 2006). This pattern is the consequence of various human activities: the introduction of non-native species (willingly or accidentally), alteration of vegetation species composition, and the creation of habitats that are similar to each other (especially in urban cores) even if they are in different regions of Earth (McKINNEY 2006, Sorace \& Gustin 2008). Accordingly, in Britain, Evans et al. (2009) did not find latitudinal gradient in avian species richness in cities, despite the fact that such gradients have been shown in non-urban areas of Europe. These successful urban-dweller species are proposed to be (pre)adapted to humancreated conditions, thus are able to flourish in urban areas all over the world, while competitively exclude non-synurbic species (Sноснат et al. 2010). This phenomenon has been referred to as biotic homogenization (McKinney 2006), including both taxonomic (reduced number of species) and functional homogenization (dominance of generalist over specialist species). Not surprisingly, the retention of native vegetation enhances the persistence of native faunal elements and also, increasing vegetation cover also positively affects species richness in the urban matrix (reviewed by Luck \& Smallbone 2010). There are studies from urban areas suggesting that native, forest species (urban avoiders) respond positively to increased and aggregated vegetation (Donnelly \& Marzluff 2006), and negatively to increasing cover of exotic urban vegetation, just contrarily to synurbic bird species (Donnelly \& MARzLUFF 2004). However, as increased levels of urbanization and the proportion of exotic vegetation are often positively correlated, disentangle the effect of vegetation from other effects of increased habitat urbanization is not easy. For example, even activities, such as bird-feeding in suburban gardens which seem to be quite harmless at first glance, could indirectly reduce local avian biodiversity, if overabundant, larger and aggressive species profit unequally more from feeders, excluding smaller, subordinant ones from the surroundings of feeding stations (Parsons et al. 2006). Species-specific responses were also highlighted by a correlative study in the UK (FulLER et al. 2008), report- 
ing positive relationships between the densities of bird feeders and certain urban-dweller species (e.g. Eurasian Blackbird or House Sparrow), while the density of some typical garden-species (e.g. Great Tit and Blue Tit Cyanistes caeruleus) was unrelated to bird feeding activity.

\section{MECHANISMS GENERATING CHANGES IN URBAN AVIAN COMMUNITIES}

Human-related environmental factors affecting the urban avifauna have been partially covered previously, including many negative direct and indirect effects. However, as we already mentioned, not all of the human activities are detrimental to birds, as one can easily infer from the often dramatic increase of the density of some urban species (e.g. Marlzuff 2001, Chace \& Walsh 2006, van ReNsburg et al. 2009). In shaping of these remarkable differences between population densities (and ultimately communities) the human-influenced food webs also play a principal role (Fig. 1). The general assumption is that cities are associated with highly increased and predictable resources and with lower predation risk (Sноснат 2004, Sноснат et al. 2006, Anderies et al. 2007). In the rest of the review, we will discuss these assumptions in details.

\section{Changes in resource-based forces}

Those populations which are limited principally by food or nutrient availability (i.e. the lower trophic levels) are termed to be under bottom-up control. The changes in resource-based forces in cities either due to the increased primary productivity or human provided food sources (e.g. seed in bird feeders, communal waste) are termed as bottom-up effect (Sноснат 2004, Fig. 1a). These are profound interventions to urban food supply dynamics and suggested to reduce birds' starvation risk and enhance reproduction (Rовв et al. 2008a). Although the effects of extra food sources on wild bird populations may seem somewhat obvious at first glance, our knowledge on this topic is far from complete.

First of all, this bottom-up effect is paradoxical, since despite the abundant resources (at population level) the high density of consumers may reduce the per capita amount of food (at individual level) due to the supposedly strong competition. This could result in resource overmatching where, ultimately, most urban individuals may not reach higher fitness compared to individuals of nonurban areas. A competition model (credit card hypothesis; Sноснат 2004) has been suggested to resolve this paradox by emphasizing the role of continuous and predictable food input in cities. The theory suggests that, on 
(a)

Changes in bottom-up regulation in cities

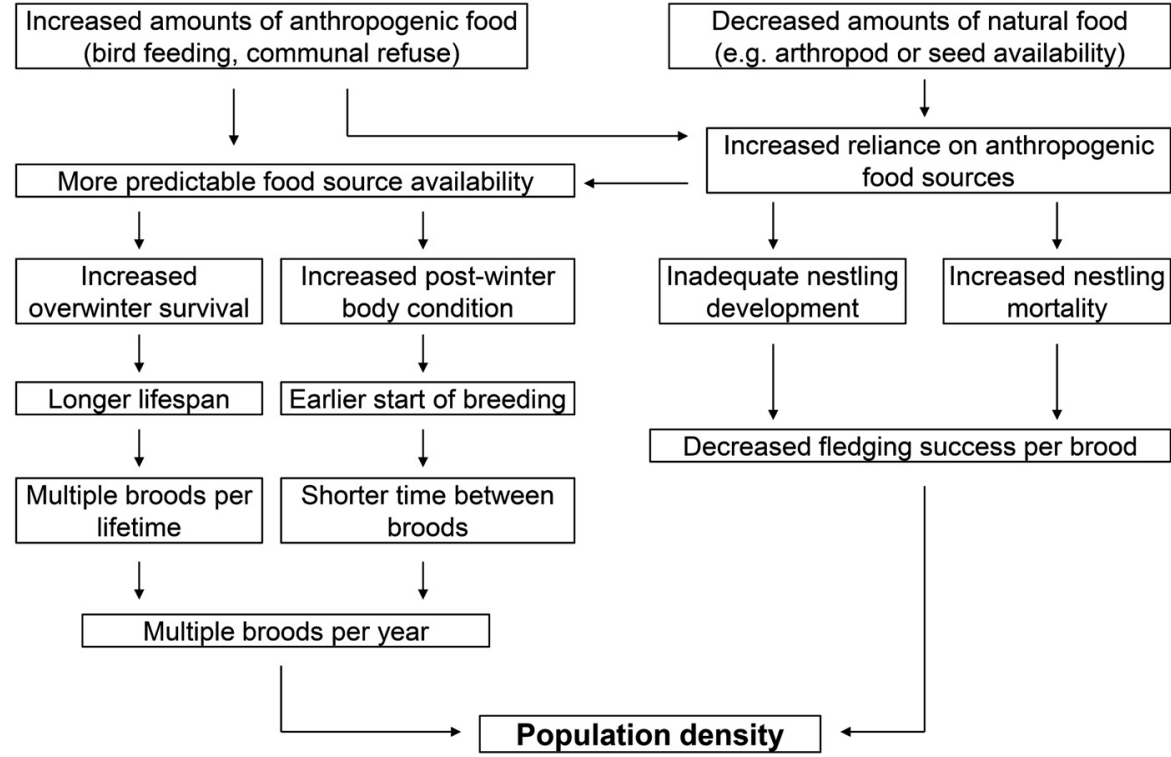

(b) Changes in top-down regulation in cities

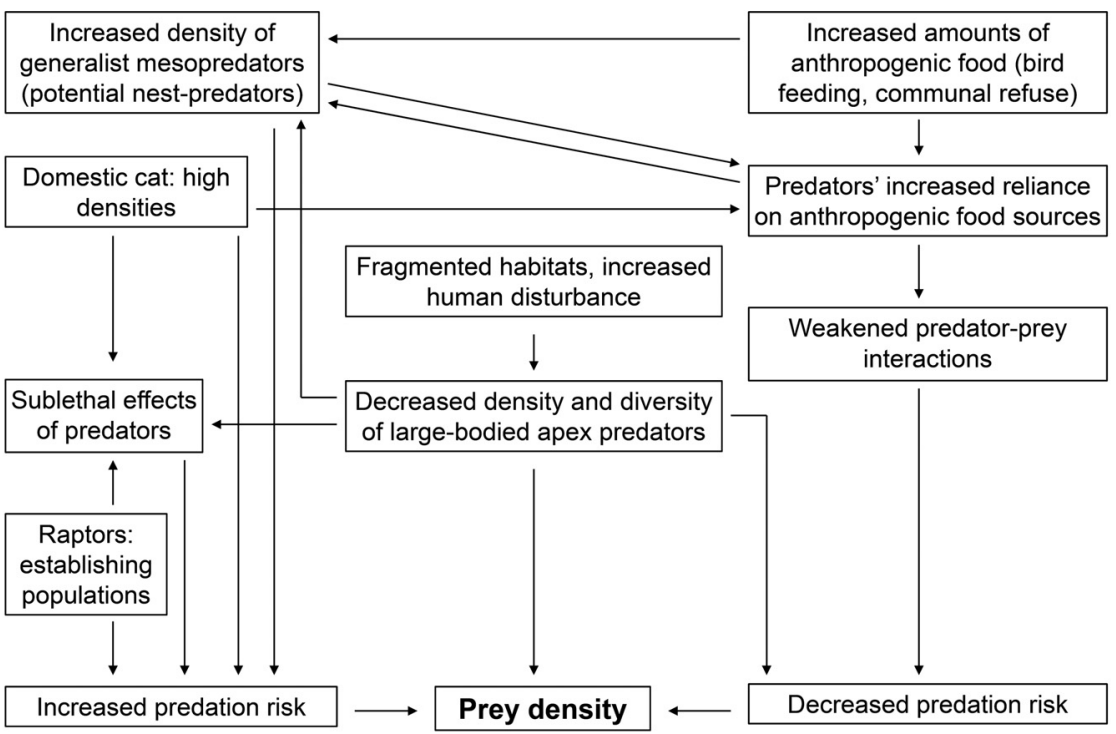

Fig. 1. Conceptualization of the effects of habitat urbanization on food-web dynamics: (a) bottom-up and (b) top-down regulation in urban areas. The impacts of human activities on urban bird populations suggested to explain the general pattern of increased prey population densities in urban areas. Arrows indicating the direction of the influence. 
the one hand, the increased avian biomass in urban areas consists mainly of poor quality individuals with inferior competitive abilities and low body reserves that can live only on a day-to-day basis in cities but would be removed by natural selection in environments with more unpredictable resource renewal. They are the losers of competition, 'living on the credit of tomorrow'. Such individuals' contribution to next generation (i.e. their reproductive success) is small, however they are accounting for a significant proportion of urban populations. At the same time, the case of competition's winners is just the contrary: they constitute the minority of the urban population, while only they are able to maintain high body reserves enough to successfully reproduce. Taken together, this theory predicts overexploitation (instead of resource matching) in cities - therefore, we should find larger populations in cities with individuals of generally inferior body condition and competitive performance, and lower average fitness, and also higher variance in these traits.

While some general characteristics of urban bird populations fits into this theory (e.g. certain species' high abundances, or the generally lower average productivity; Chamberlain et al. 2009a), other findings on successful synanthropic bird species do not support the model's predictions. For example, a study conducted on the Northern Cardinal Cardinalis cardinalis estimated the species' density in urban forests to be four times higher compared to rural areas, yet it did not find any significant habitat related differences in annual breeding success (mean of fledged chicks per pair), apparent survival rates and body condition (Rodewald \& SHUSTACK 2008). A recent study on the house finch (Giraudeau \& McGraw 2014) reported some negative relationships between urbanization and certain metrics of birds' physiology (e.g. levels of vitamin A and plasma carotenoid), but none of these differences were consistent throughout the year, suggesting only season-specific, but not yearround and long lasting detrimental effects of urbanization on birds' quality. Likewise, studies of the house sparrow found no evidence of any systematic, urbanization-related differences in stress responses, physiology, coloration, or body condition of adults, although birds of urbanized habitats were found to be proportionally smaller (but not leaner) compared to their rural conspecifics (LiKer et al. 2008, BóкоNy et al. 2012). In another study, urban and rural sparrows neither differed in their competitive performance, nor did the authors found any relation between individuals' body mass, competitive success or in variance of competitive abilities (ВóкоNy et al. 2010). Similarly, a recent study on the song sparrow failed to find detrimental effects of increased habitat urbanization on birds' stress physiology and body condition (GRUnst et al. 2014). These results do not support the credit card hypothesis; furthermore the above findings on house sparrows also imply that the smaller body size of adult urban birds may not necessarily denote inferior physical condition or poorer competitive abilities. 
It is generally accepted that increased food abundance and predictability is a major driver of increased avian biomass in urban areas (Fuller et al. 2008). For example, several gull species (e.g. НАтсн 1996) or ibises Threskiornis sp. in Australia (MARtin et al. 2011) and Europe (Clergeau \& Yésou 2006) utilize and thrive in urban landfills. But humans not only unintentionally provide food for wildlife. Bird feeding in residential gardens is quite a common practice in many parts of the world: in the UK, for example, ca. $50-75 \%$ of the surveyed households are estimated to provide food, most frequently bread, fat and peanuts, for birds, which comes out at hundreds of thousand tons of food annually (CowIE \& Hinsley 1988, Davies et al. 2009). Such amount of anthropogenic food has the potential to substantially affect urban birds' reproduction either by influencing parents or nestlings through numerous ways. Thus, in order to better understand the underlying mechanisms by which extra food influences breeding success, we should separate its effects on adult birds and their nestlings.

Let us begin with adult birds. The constraint hypothesis (PERRINS 1965) predicts that low food availability in the pre-breeding period, due to energy and/or nutrient poverty, restrains female's egg formation. However, in urban habitats the extra food, along with the decreased energetic demands prior breeding (due to the milder climate), supposedly enhance both overwinter survival and body condition of adults. The generally earlier egg-laying dates of urban passerines (CHAMberLain et al. 2009a) in cities might reflect this better condition; however, on the very same basis, larger clutch size, at least in the first nesting attempt, should also be expected in urban habitats. But this is not the general pattern (see the review of Chamberlain et al. 2009a), and e.g. the similar body condition of Northern Cardinals, House sparrows (captured in October-Februar) or Song Sparrows (in breeding season) in differently urbanized areas also contradicts the generality of urban birds' better pre-breeding condition (Rodewald \& Shustack 2008, BóKony et al. 2012, Grunst et al. 2014). An other theory (the anticipation hypothesis, LACK 1954) suggests that the increased availability of human-supplied food preceding the breeding season might serve as a cue for females, indicating suitable future conditions for chick rearing periods, thereby triggering their earlier start of breeding. In this sense birds depend on information of their environment's quality. If we take into consideration that in the temperate climate zone bird feeding generally stops as spring arrives, such winter food supplementation might be a misleading cue for birds, creating an ecological trap, as it may falsely predict enhanced food abundance later in the breeding season. The outcome of such early breeding could result in a mismatch between the peak of natural food availability and nestlings' food demand, ending up in decreased chick survival. In line with this theory, supplementary food experiments often report advanced laying dates (e.g. see the review of Rовв et al. 2008b), but much less 
frequently found any substantial increase in clutch size (e.g. Blue Tit, Ramsay \& Houston 1997, Great Tit, NAger et al. 1997), although larger clutches in some supplemented birds are also reported (e.g. Florida Scrub-jay Aphelocoma coerulescens, Sсновсн 1996).

It is also important to disentangle the short- and longer-term effects of food supplementation to birds' body condition and breeding success. Furthermore, food supplementation before or during the breeding season might have different effects. To distinguish between short- and longer-term effects, Rовв et al. (2008b) conducted a landscape-scale experiment on Blue Tits in woodland habitats, where peanuts was subsidized ad libitum for months, but was suspended six weeks before egg-laying. They found that birds at supplemented sites initiated egg-laying earlier and fledged more young per nest, however, clutch size, hatching ratio or fledgling mass were similar between the treated and control groups. The authors concluded that higher nestling survival at the subsidized sites was supposedly the result of improved parent condition that could enhance parental care. A similar study on the same species (Plummer et al. 2013a) proved that quality of food provided during winter is also important, as fat provision had negative effects on egg quality in the subsequent breeding season, whereas this effect was mitigated when fat was amended with vitamin E. A possible explanation for this result is that birds may have become dependent on such easily accessible, energy-rich food source; though it may have enhanced their overwinter survival, it reduced their dietary diversity, leading to that they failed to build up reserves of key nutrients important in egg formation. In a follow-up study with the same design (Plummer et al. 2013b) fat supplement had similarly no effect on clutch size, but had detrimental effects on the number, weight and size of fledged young. In a three-year long study of woodland great tits and blue tits, several week long food supplementation until hatching yielded some surprising outcome, as the authors found reduction in both clutch size and number of hatched young in the treated groups (HARRIson et al. 2010). These results are difficult to interpret, but one possible explanation is again the suboptimal nutrient content of the provided food ('peanut cake' which is fat-rich but protein-poor) leading to dietary deficiency. Alternatively, bird feeding may increase adult survival, and, as predicted by life-history theory, birds with longer life expectancy may reduce their breeding investment per brood. The influence of diet quality was also emphasized by Reynolds et al. (2003) who found that laying date, egg mass and clutch size were increased in florida scrub-jays supplemented with protein- and fat-rich food, but not in groups fed with fat-rich food only; however, the increment in clutch size was yeardependent, possibly reflecting differences in natural food availability. 
These studies demonstrate that food supplementation may not always be self-explanatory beneficial for adult birds, as supplementary feeding has the potential to disrupt the natural patterns of avian reproduction. Their results also indicate that impacts of bird feeding are species-specific, furthermore likely to depend on the given year and natural resource availability, quality of the offered food, and also highlight that the long-term effects of abundant supplementary food sources on individuals and populations are poorly known. Although most of the above cited supplementary-feeding studies were not conducted in urban habitats, many of the differences found between fed and unfed tits (e.g. earlier laying, smaller broods and chicks) can also be found between these species' urban and non-urban populations (CHAMBERLain et al. 2009a), suggesting that abundant anthropogenic food sources might play a role in this pattern. We only remark here, that beyond the direct physiological impacts we have discussed above, bird feeding is potentially involved in a number of other effects on wild bird populations, including several behavioural changes, competition for territories, increased disease transmission or changes in dispersal or migration patterns, etc. (Jones \& ReYNolds 2008).

As regarding of the nestlings, the high proportion of anthropogenic food may shift their diet towards higher ratios of 'junk food', especially when natural food is scarce. This assumption has gained some evidence in a food-choice experiment with wildland and suburban Florida Scrub-jays where, during nestling rearing parents showed stronger preference to natural food (waxworm) over human-provisioned (peanut), regardless of habitat. However, when handling time of arthropod food was experimentally increased, they switched to higher ratios of peanuts; but suburban parents were still more likely to choose natural food. These results are suggested to indicate reduced arthropod availability in suburban habitats (SAUTER et al. 2006) as it was also found in a former arthropod-monitoring study in the species' suburban and wildland habitats (SHAwKEY et al. 2004). Results on urban-dweller European starlings also showed that their nestling diet contains more human refuse compared to those of less urbanized habitats (Mennechez \& Clergeau 2001, 2006). Studies on Australian Magpies Gymnorhina tibicen, a common species in the suburbia, found that nestlings of pairs that regularly visit feeding stations receive less natural food compared to the chicks of those parents that were never recorded to forage on bird feeders (68\% vs. 97\%, respectively; O'LeARY $\&$ Jones 2006). However, while the altered palette of urban food sources can be more or less appropriate for adult birds, it may not so suitable for nestlings, requiring protein-rich diet. Supporting this, compared to nestlings of less urbanized habitats, urban ones often reach lower body mass (e.g. European Starling; Mennechez \& Clergeau 2001, 2006), Western Gulls Larus occidentalis (Pierotti \& Annett 2001), American Crows Corvus brachyrhynchos (Heiss et al. 2009) or Great Tit (HõraK et al. 2000) and suffer from higher mortality (СнAм- 
BERLAIN et al. 2009a), as reduced nestling body size of urban chicks can be associated with increased mortality as was shown e.g. in the House Sparrow (РеACh et al. 2008, Seress et al. 2012, Fig. 2). Nestling size also strongly predicts later fledging success in the Great Tit (Plummer et al. 2013b), and size prior to fledging is known to be a good predictor of later recruitment as a breeding adult in many bird species (SCHWAGMEYer \& Mock 2008). Thus, the quantity and/or quality of nestling food is one of the most crucial factors for chicks, as early nutritional conditions strongly affect both their survival and development. Moreover, the results of some experimental studies e.g. in the House Sparrow (Anderson 2006), Song Sparrow (Searcy et al. 2004) and Western Gull (Pierotti \& Annetr 2001) suggest that developmental fallbacks are carried over to adulthood. The positive effects of high quality nestling food on nestling production also has some support from experimental studies. For example, urban Carrion Crow Corvus corone corone pairs supplemented with protein-rich food during chick rearing produced more and greater-sized fledglings (RICHNER 1992). Parkland great tits supplemented with mealworms from hatching to fledging produced heavier nestlings, but the number of fledged young was not affected; although, whether parents consumed the extra food or they fed it to their nestlings, is largely unknown from this study (BANBuRA et al. 2011). A recent study on House Sparrows also demonstrated increased nestling production in mealworm-supplemented nests, although this increase was similar in suburban and rural habitats (РеACH et al. 2014). The impacts of nestling diet were also supported by a study in which urban and rural house
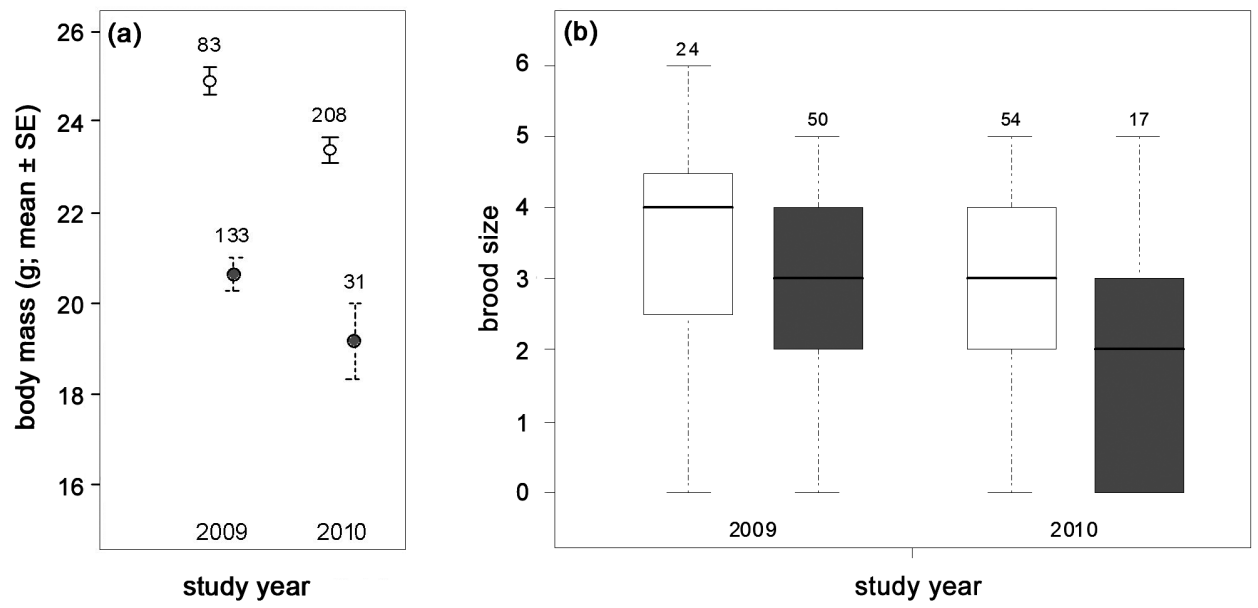

Fig. 2. Differences in (a) nestling growth (as measured by body mass before fledging) and (b) breeding success (as measured by brood size before fledging) in House Sparrows living in rural (white) and suburban (grey) habitats in Hungary in 2009 and 2010. The number of (a) nestlings and (b) nests are shown in each graph (data obtained from SEREss et al. 2012) 
sparrows were kept in aviaries supplied with ad libitum food of diverse composition: these birds performed similarly in all aspects of breeding parameters, despite the marked differences found between free-living suburban and rural populations of the same geographic region (Seress et al. 2012).

Thus, a plausible explanation for certain urban passerine birds' lower reproductive success and their nestlings' smaller size can be the lack of high quality nestling food, e.g. arthropods which show reduced abundance and/or diversity with increasing urbanization (SHOchat et al. 2004, Fiera 2009, McIntyre \& Rango 2009, Niemelä \& Kotze 2009, Raupp et al. 2010, van Nuland et al. 2014). While available quantitative data on densities and diversities of many arthropod taxa are poor, the elevated levels of pollutants, the higher proportion of pavement cover, the increased usage of pesticides in residential gardens and park areas, the strong thinning of shrub layer, mown turf and the removal of leaf litter in green spaces, and also the high proportions of exotic plants are all assumed to reduce their presence in urban areas. The importance of tree patches and certain native plant taxa was also demonstrated by a recent paper investigating foraging choices of two parid species in a diverse urban green patch (MACKENZIE et al. 2014). This study found that blue tits foraged more on native plants than on exotics, and also preferred deciduous vegetation over evergreens - but this selectivity decreased in the nestling rearing period, probably because the increased time constraints. Great tit parents were not so selective before hatching, but similarly preferred native deciduous vegetation over evergreens - although, somewhat surprisingly, they preferred non-native plants to natives after fledged their young. The general preference in both species for larger, deciduous trees over other types of vegetation possibly shows greater arthropod richness of this vegetation.

Those arthropod groups which are positively or not affected by urbanization are typically smaller sized (such as aphids) or more or less unavailable for many insectivorous birds (e.g. dust mites, leaf-mining moths or gall-forming taxa; RAupp et al. 2010). Furthermore, the size of individual arthropods within a taxa is also known to be reduced in urbanized and polluted environments (Niemelä \& Kotze 2009, Zvereva \& Kozlov 2010) which may further decrease their availability and value as nestling food. According to this, a study on chick-feeding behaviour of the same species provides direct evidence for the hypothesis that suburban nestlings receive diet of lower quality and/or quantity as their parents delivered significantly fewer large prey items e.g. large caterpillars or orthopterans than those in rural habitats (SEREss 2014). These large prey items seem to be the most valuable type of nestling food since their delivery rate strongly predicts fledging mass and recruitment (SCHWAGMEYER $\&$ Моск 2008). In their study Schwagmeyer and Моск (2008) made an attempt to translate invertebrate food size into food value and estimated that a single 
large prey item's $(>2 \mathrm{~cm})$ dry weight is $30-40$ times greater, thus it is significantly more valuable than a small one $(<0.6 \mathrm{~cm})$. It is not yet known, however, whether a large prey item is superior merely due to the disproportionately larger quantity of nutrients it provides (SCHWAgmeYer \& Mоск 2008) or because it represents specific taxa of particular nutritional value (e.g. spiders contain high levels of taurine, Ramsay \& Houston 2003).

\section{Changes in consumer-based forces}

Populations are under top-down control when trophic interactions from higher levels of the food web - in this case predation pressure - is their main limiting factor. The background mechanisms affecting these consumer-based forces of urban food webs are rather complex and substantially influenced by human activities (Fig. 1b). However, despite its potential importance as a driver of urban bird community dynamics, the changes of top-down forces are poorly understood, even less than those of the bottom-up control mechanisms.

The general assumption is that predation pressure is reduced in urban areas (also known as predation-relaxation or safe-zone hypothesis) which is mainly based on urban birds' reduced fearfulness to humans and the sometimes low abundance of their native predators (GERING \& BlAIr 1999, SноснаT et al. 2006). The predation relaxation is suggested to partially explain the great biomass of avian prey species in cities.

On the one hand, there are studies reporting higher or similar survival rates of prey species in urban than in rural areas (e.g. reviewed by Evans 2010, FisCHER et al. 2012) which can be attributed to lower predation rates in urban habitats. This is an indirect approach, however, as higher survival rates may result from several other factors (e.g. more predictable food, milder climate or reduced migratoriness). Therefore estimating survival rates as a proxy of predation pressure do not give us details on the background mechanisms. An alternative is to quantify and compare prey species' antipredator behaviour along the urbanization gradient. One common approach uses the flight initiation distance (FID) to assess the actual predation risk perceived by prey. The FID measures the distance at which an animal flushes away when a potential predator or novel object approaches; hence, it is thought to be informative on predation risk in different environments as birds exposed to greater predation risk are expected to show a stronger propensity to escape, i.e. longer FIDs (i.e. flush earlier; StANкоwich \& Blumstein 2005). When comparing populations of the same species, FIDs are consistently shorter in urbanized areas (e.g. Møller 2008), even in relatively sensitive raptor species (e.g. Keeley \& BeCHARD 2011). However, an important caveat is that FID is usually measured as a reaction to approaching humans (e.g. in the above studies), yet it is used as a 
proxy for representing general predation risk perceived by birds. This may be false if birds distinguish humans and other predators in terms of dangerousness which can be plausible as most humans do not hunt or persecute birds in urban areas (but this can species- and region-specific, see CluCAS \& MARZLUFF 2012) opposed to sparrowhawks, cats or other predator species. Thus, as in urban areas increased boldness toward anthropogenic disturbances is hypothesized to be beneficial (MøLler 2008), such bold behaviour may not be adaptive as a response to predators. Whether FID is a reliable approach for assessing perceived predation risk in general is questionable and still requires further investigations. Irrespective of this problem, the studies of FID suggest a plausible mechanism that can reduce predation risk at least for some urban birds. Since FIDs are found to be much higher in larger-bodied, predatory species than in small prey species, the presence of humans in cities can often create predator-free refuges for the tamer prey species (MøLLER 2012).

On the other hand, contrarily to the predation-relaxation assumption, the overall abundances of certain potential predators like corvids (JoKIмÄKI \& Huhta 2000, Marzluff et al. 2001, Marzluff \& Neatherlin 2006) or mammalian, omnivorous mesopredators (e.g. raccoons, mustelids; Prange et al. 2003, Herr et al. 2008, Tóth et al. 2011, Ćervinka et al. 2014) are frequently higher in urban environments compared to adjacent, more natural habitats (RODEWALD et al. 2011, ŠÁLEK et al. 2015). The results of growing number of monitoring studies demonstrate that many predatory species have the ability to adapt to and gain from human altered landscapes and have increased their urban populations recently. Likewise, non-native mesopredator species, e.g. the Domestic Cat Felis catus can also reach extremely high densities in cities, far above their natural carrying capacity (LEPCZYK et al. 2003, BAKER et al. 2008, Sims et al. 2008). The fact that these predators reach the highest numbers in urban habitats (e.g. Haskell et al. 2001, Sorace 2002), yet their avian prey species also thrive there in great numbers, entail contradictory predictions on the importance of topdown control, leading to a predation paradox which seems to be a widespread phenomenon in urban habitats (FISCHER al. 2012). This paradox questions if urban bird populations are strongly top-down regulated (Sноснат 2004).

A number of factors make it difficult to evaluate this paradox. First, predation on fledged juveniles and adult birds and predation on nests involve different predators. While raptors prevailingly prey upon adult birds, many feral, mammalian mesopredators and corvids (magpies, jays and crows) are usually known to prey mainly upon eggs and nestlings (e.g. Јокімёкі \& Huhta 2000, Marzluff et al. 2001). However, response of predators to urban environment is complex. Similarly to prey species, urbanization filters different predator species as well, favoring generalists over specialists (e.g. JokiмёKi \& Huhta 2000, Sorace \& Gustin 2009) - hence the densities of these two predator groups are assumed to change differently along the urbaniza- 
tion gradient. For instance, the absence of vulnerable apex-predator species in urbanized areas may lead to mesopredator release (Ritchie \& JoHnson 2009), indirectly increasing predation rates of both nests and fledged birds (Rogers \& CAro 1998, Своокs \& Soulé 1999). Additionally, it seems that large-bodied carnivores and snake species respond negatively to urbanization, while generalist bird and omnivorous mammal predators fare much better in urban environments reaching high abundances, especially in the case of some introduced predators (FIsCHER et al. 2012). Despite their high densities, however, it is debated whether these potential predators act as actual predators or rather rely on anthropogenic, easily accessible food sources (e.g. garbage or subsidized food for pets). If omnivorous predators shift their diet and consume alternative food sources instead of hunting, this results in lower actual predation rates than it would be assumed by predators' abundance alone (e.g. Rodewald et al. 2011). Some results support this theory in the case of corvids. Corvids are often abundant in cities, but despite their high numbers, correlative studies based on common bird census data in Britain failed to find negative relationships either between the densities of these nest predators and their preys and avian densities (Evans et al. 2009), or species richness (Sims et al. 2008). In line with this, the removal of the common nest-predator Blackbilled Magpies Pica pica from suburban parks in Paris did not yield increment in the ten monitored songbird species' populations (CHIRON \& Julliard 2007). To assess the impact of such nest predators, the applying of artificial nests is far the most frequent method. However, despite of the plenty of published papers so far, the findings are conflicting, leaving the relationship between habitat urbanization and nest predation rates equivocal (see e.g. CHAmberLAIN et al. 2009a, RodewALD et al. 2013). For example, in a decade-long monitoring study, involving more than a thousand natural nests in forest patches along the urban gradient the authors did not found consistent relationship between degree of urbanization and daily nest survival rates (RoDEwALD et al. 2013). This result is interesting, because increasing urbanization and the occurrence of many mesopredator species was positively correlated - but nest predation rates related to predator densities only in rural habitats, and not in urban forest patches (Rodewald et al. 2011). Concluding these results, it seems that certain type of predators' reliance on anthropogenic food sources may have the potential to weaken the trophic linkages between predators and prey, and with the drastically elevated prey numbers, this may consequently lead to reduction in actual predation pressure. Additionally, it is also possible that urban bird communities contain greater proportion of species that have effective nest defense mechanisms against urban-adapted predatory species, thus are less vulnerable to nest predation (STRACEY \& RoBinson 2012).

Although abundant alternative food sources may decouple interactions between prey and certain predator species, this is usually not the case for 
urbanizing raptor species which rarely feed on human refuse or subsidized food. Despite their former negligence as important predators in cities, the response of raptor species to urbanization can also quickly change: a number of carnivorous bird species that were formerly absent as breeders in urban areas have been documented to establish breeding populations within cities recently (CHACE \& WALSH 2006) such as the Eurasian Sparrowhawk Accipiter nisus, the Northern Goshawk Accipiter gentilis (Rutz 2008), the Eurasian Kestrel Falco tinnunculus (Salvati et al. 1999, KüBler et al. 2005, Morandini 2006, Sumasgutner et al. 2014) or the Merlin Falco columbarius (Sodhi \& Oliphant 1992), supposedly responding to abundant prey populations and/or availability of nest sites in cities, or a delayed response to the decreased prosecution by humans. For example the Eurasian Sparrowhawk is known to be one of the principal predators of smaller bodied songbird species, and its numbers are increasing in several urbanized habitats (CHAMBERLAIN et al. 2009b), reaching high densities in large European cities like Hamburg (Risch et al. 1996) or Prague (Kelcey \& Rheinwald 2005). In Budapest, Hungary, breeding Sparrowhawks are present from the early 1980's (BAGYURA 1985) and in 2007, the number of breeding birds was estimated around 200 pairs (BÉRCES 2007) which exceeds the breeding density of sparrowhawks in many natural habitats (Newton 1986). Furthermore, the number of sparrowhawks hunting in Budapest during winters is assumed to reach 500-600 individuals ( $\mathrm{Z}_{\text {. BA- }}$ JOR, pers. comm.). Similarly, in a recent study, the Eurasian Kestrel's breeding density was estimated to reach $89-122$ breeding pairs $/ 100 \mathrm{~km}^{2}$ in Vienna, with the highest density in the city centre (SUMASGUTNER et al. 2014). Such elevated ratio of predators to prey may increase predation risk, especially if raptors adapt their diet to the altered prey species composition of cities. Such a diet shift was reported in urban kestrels (e.g. Kelcey \& Rheinwald 2005, KüBleR et al. 2005), as they consume higher ratios of avian prey, due to the lower availability of diurnal rodents in the more heavily urbanized areas (SumasGUTNER et al. 2014); however, nocturnal raptors, such as the Tawny Owl Strix aluco are also known to take more bird prey items in urban areas (GoszczYNSKI et al. 1993). Therefore, the fact that numerous studies report increasing breeding populations of various raptor species in urban areas infers that their population-regulatory role in urban areas should not be so easily dismissed. Strengthening this assumption, a study from Britain found that the start of urban house sparrow populations' decline is fairly coincident with the recovery and continuous spread of sparrowhawk populations, and their colonization of urban habitats after the ban on DDT use (Bell et al. 2010). Consistently with this, an experimental study also demonstrated that predation pressure perceived by a common prey species varies in relation to urbanization (SERESS et al. 2011). By manipulating predation risk, the authors found that urban house sparrows responded more strongly to simulated Sparrowhawk attacks than 
rural birds, and also that birds' fearfulness highly increased with age (from young to older birds) in urban but not in rural sparrows. These results suggest different experiences with raptors during their lifetime in their original habitat, and do not support the assumption of decreased predation risk in cities, at least posed by the Sparrowhawk.

Finally, we have to highlight the situation of a special predator, the domestic cat which is virtually present all over the world's urban areas. Cats are known to pose threat mainly to fledged birds (especially to juveniles), although their role as nest predators in urban areas is also documented (RoDEwald \& Kearns 2011, Stracey 2011). As this species reach high densities in urban areas compared to any native predator (e.g. Thomas et al. 2012), and readily hunt down wild species even when being subsidized, it is not surprising that cat predation is considered among the most important human-related causes of bird mortality (BAKer et al. 2005, Dauphiné et al. 2009, Stracey et al. 2011, Loss et al. 2013). However, as experimental manipulation of cat density in the urban matrix is problematic, proving or disproving their actual impact on prey species' population size is difficult. A frequent approach, therefore, to estimate cats' predation rates is based on surveying cat owners about the number of their pet's returned prey. Converting these data to actual and typical predation rate also has some limitations, because prey returning rates are proven to be highly variable, depending on the individual cat, the season or the owners' behaviour (Thomas et al. 2012). A further important caveat of this method has been also demonstrated by a recent paper from the USA (LoyD et al. 2013). This study applied cat-borne video cameras to record pet cats' activity, and reported that only $23 \%$ of their prey items were carried home, implicating that previous studies based on cat owners' surveys certainly and highly underestimated the actual predation rates posed by free-ranging cats. Whether this proportion is only the doomed surplus of prey populations (i.e. individuals that would have died anyway e.g. from age or parasites) and cats are causing only compensatory mortality or cat-posed mortality significantly contributes to certain species' population loss, is still an open question.

Beside depredation, the sublethal effects of cats to birds were also gained empirical support recently, as in their current study BonNINGTon et al. (2013) showed that the mere presence of cats around nests resulted in reduced parental provisioning rates and increased chance of nest predation - the latter due to the conspicuous parental nest defence behaviour given to the cats. However, as usually, the impact of Domestic Cats on urban avifauna seems to be species-specific. In line with this a wide-scale correlative study in Britain (Sims et al. 2008), involving urban bird and cat populations did not find a general negative correlation between bird and cat densities, instead they found that individual bird species responded differently. At the same time, this study found negative relationships between the avian species richness and 
cat densities, especially in groups of birds termed vulnerable to cat predation (e.g. small bodied birds, foraging often close to the ground). The long-time and ubiquitous presence of cats and the lack of general negative correlations between predator and prey densities may also suggest that present species composition of urban aviafauna represents a subset of species which are selected to be resilient to cat predation (Sноснат 2004).

\section{CONCLUSIONS}

In this review we showed that several aspects of habitat urbanization have important consequences on bird populations. As illustrated above, seemingly simple factors like food availability and predation risk may have complex effects on urban birds. However, while a great amount of case studies has been conducted so far, especially from the latest decade, their results are often conflicting - thus, it is clear that our current knowledge on the ecological determinants of urban avian communities is far from complete. In this final section we discuss some of the most important caveats limiting our current state of understanding and we also propose some future research directions.

Biases in model species and geographical regions are perhaps the most prominent shortcomings of the accumulated literature. Regarding of the former, a considerable part of the studies has been conducted on a few and relatively common passerine species (e.g. sparrow or tit species, or the Eurasian Blackbird). However, this raises the question that to what extend should we expand these findings to other bird species? For example, while it seems to be somewhat consistent that the adults of small passerine species living in urban and non-urban areas do not differ in their body condition, a study on Silver Gull Larus novaehollandiae populations found urban males to have ca. $10 \%$ greater mass and body condition compared to males of a non-urbanized island (Auman et al. 2008). This may suggest that different species may respond differently to similar urban environmental conditions. Regarding of the geographical bias, most of the studies were conducted in Europe or North America, which again clearly limits the potential to generalize their findings. Additionally, information from the most heavily influenced, core regions of cities are also very scarce, leaving us with little insight into this part of the urbanization gradient. Further limits our overall understanding on urban ecological forces that while generalizations on changes in bottomup control (i.e. predictable and high resource availability) seem to describe a more or less widespread pattern of various urban landscapes, the changes in top-down control might be far more location-specific. Predators' response to habitat-urbanization and their top-down regulatory role could depend on a great number of factors, including: species composition of the native predator fauna; predators' timing of establishing urban populations; development of 
the urban landscape (e.g. expansion of green belts); availability of certain resources (e.g. suitable nesting sites); the former and present attitude of humans to certain predator species (e.g. persecution of raptors) which influence their present tolerance and fearfulness to humans; or the introduction of elsewhere successfully adapted, non-native predator species (e.g. raccoons) to ecosystems. These factors may greatly vary from region to region, strongly influencing an urban area's current predator fauna, therefore the actual predation pressure on prey populations. This variety may even make it doubtful to identify a clear-cut, general trend in changing predation pressure along an urban gradient that would be applicable in wide geographical regions. Thus, in order to help to re-evaluate recent, supposedly simplistic conceptions, more studies on more species are needed from different climatic zones, and from broader scales of urban gradients.

Additional research would also be useful to evaluate the contradictory role of the most abundant urban predator, the Domestic Cat. Monitoring not just cats' diet components or predation rates per se, but also the availability, density and population size of their prey species at the same time (e.g. as done by vaN HeeziK et al. 2010) would be helpful in identifying susceptible wild species and their characteristics, and also to determine whether the considerable mortality caused by this predator is an actual population limiting force in cities, or not. Besides direct mortality, predators' sub-lethal effects on prey populations are also need to be addressed more thoroughly. Predators' mere presence is known to be detrimental to prey via numerous non-lethal effects (e.g. altered habitat use, increased stress levels, reduced foraging or nestling provisioning), the impact of which to prey populations may even exceed that of killing (reviewed by CRESSwELL 2009) especially in areas with high predator densities. Focusing more research interest to explore these subtle effects (e.g. as done by BonNington et al. 2013) would also contribute to gain a more realistic and complete picture on predators' actual regulatory role in urban areas.

Regarding of the bottom-up control, descriptive studies e.g. on urban passerines' dietary components in chick-rearing period could help us to determine on which extent these species rely on anthropogenic food sources. Additionally, more emphasis on experimental research would also be very useful. For example, manipulating food availability at sites with different degree of habitat urbanization, followed-up by monitoring birds' responses (e.g. reproduction, body condition, territory size), would help to assess the importance of this force.

Such research directions would help us to understand the mechanistic roles of the changes human activities generate in urban food webs, and to advance from only documenting patterns of urban bird communities to understand the underlying processes shaping them. 
Acknowledgements - This research was supported by the European Union and the State of Hungary, co-financed by the European Social Fund in the framework of TÁMOP4.2.4.A/ 2-11/1-2012-0001 'National Excellence Program', and by the OTKA K84132 grant.

\section{REFERENCES}

Anderies, J. M., Katti, M. \& Shochat, E. (2007) Living in the city: resource availability, predation, and bird population dynamics in urban areas. Journal of Theoretical Biology 247: 36-49. doi: 10.1016/j.jtbi.2007.01.030

ANDERson, T. R. (2006) Biology of the ubiquitous house sparrow: from genes to populations. New York, Oxford University Press, 560 pp.doi:10.1093/acprof:oso/9780195304114.001.0001

Andrews, K. M., Gibbons, J. W. \& Jochimsen, D. M. (2008) Ecological effects of roads on amphibians and reptiles: a literature review. Herpetological Conservation 3: 121-143.

Arnold, T. W. \& ZinK, R. M. (2011) Collision mortality has no discernible effect on population trends of North American birds. PLoSONE 6: e24708. doi: 10.1371/journal. pone.0024708

Auman, H. J., Meathrel, C. E. \& Richardson, A. (2008) Supersize me: does anthropogenic food change the body condition of Silver gulls? A comparison between urbanized and remote, non-urbanized areas. Waterbirds 31: 122-126. doi: 10.1675/1524-4695(2008)31[122:SMD AFC]2.0.CO;2

BAGYuRA, J. (1985) Karvalyok (Accipiter nisus) alkalmazkodása a városi környezethez. [The sparrowhawk's (Accipiter nisus) adaptation to urban environment.] Madártani Tájékoztató 1985(júl.-dec.): 68-70. [in Hungarian]

Baker, P. J., Bentley, A. J., Ansell, R. J. \& Harris, S. (2005) Impact of predation by domestic cats Felis catus in an urban area. Mammal Review 35: 302-312. doi: 10.1111/j.13652907.2005.00071.x

Baker, P. J., Molony, S. E., Stone, E., Cuthill, I. C. \& Harris, S. (2008) Cats about town: is predation by free-ranging pet cats Felis catus likely to affect urban bird populations? Ibis 150: 86-99. doi: 10.1111/j.1474-919X.2008.00836.x

Banbura, J., Banbura, M., Gladalski, M., Kalinski, A., Markowski, M., Michalski, M. Nadolski, J., Skwarska, J. \& Zielinski, P. (2011) Body condition parameters of nestling Great Tits Parus major in relation to experimental food supplementation. Acta Ornithologica 46: 207-212. doi: 10.3161/000164511X625991

Barber, J. R., Crooks, K. R. \& Fristrup, K. M. (2009) The costs of chronic noise exposure for terrestrial organisms. Trends in Ecology and Evolution 25: 180-189. doi: 10.1016/j. tree.2009.08.002

Bell, C. P., Sam, W. B., Parkes, N. G., Brooke, M. D. L. \& Chamberlain, D. (2010) The role of the Eurasian sparrowhawk (Accipiter nisus) in the decline of the house sparrow (Passer domesticus) in Britain. The Auk 127: 411-420. doi: 10.1525/auk.2009.09108

Benítez-López, A., Alkemade, R. \& Verweij, P. A. (2010) The impacts of roads and other infrastructure on mammal and bird populations: A meta-analysis. Biological Conservation 143: 1307-1316. doi: 10.1016/j.biocon.2010.02.009

BÉrCEs, J. (2007) A fővárosi karvalyok (Accipiter nisus) fészkelési szokásairól. [Breeding habits of the sparrowhawk (Accipiter nisus) in Budapest] Heliaca 1: 99-108. [in Hungarian] 
Bichet, C., Scheifler, R., Coeurdassier, M., Julliard, R., Sorci, G. \& Loiseau, C. (2013) Urbanization, trace metal pollution, and malaria prevalence in the House Sparrow. PLoSONE 8: e53866. doi: 10.1371/journal.pone.0053866

BLAIR, R. B. (1996) Land use and avian species diversity along an urban gradient. Ecological Applications 6: 506-519. doi: 10.2307/2269387

BLAIR, R. B. (1999) Birds and butterflies along an urban gradient: surrogate taxa for assessing biodiversity? Ecological Applications 9: 164-170. doi: 10.1890/1051-0761(1999) 009[0164:BABAAU]2.0.CO;2

Bonnington, C., Gaston, K. J. \& Evans, K. L. (2013) Fearing the feline: domestic cats reduce avian fecundity through trait-mediated indirect effects that increase nest predation by other species. Journal of Applied Ecology 50: 15-24. doi: 10.1111/1365-2664.12025

Во́коny, V., Kulcsár, A. \& Liker, A. (2010) Does urbanization select for weak competitors in house sparrows? Oikos 119: 437-444. doi: 10.1111/j.1600-0706.2009.17848.x

Вóкоny, V., Seress, G., Nagy, S., Lendvai, Á. Z. \& Liker, A. (2012) Multiple indices of body condition reveal no negative effect of urbanization in adult house sparrows. Landscape and urban planning 104: 75-84. doi: 10.1016/j.landurbplan.2011.10.006

Brumm, H. (2004) The impact of environmental noise on song amplitude in a territorial bird. Journal of Animal Ecology 73: 434-440. doi: 10.1111/j.0021-8790.2004.00814.x

Č́ervinka, J., Drahníková, L., Kreisinger, J. \& Š́́lek, M. (2014) Effect of habitat characteristics on mesocarnivore occurrence in urban environment in the Central Europe. Urban Ecosystems 17(4): 893-909. doi: 10.1007/s11252-014-0364-1

Chace, J. F. \& Walsh, J. F. (2006) Urban effects on native avifauna: a review. Landscape and Urban Planning 74: 46-69. doi: 10.1016/j.landurbplan.2004.08.007

Chamberlain, D. E., Cannon, A. R., Toms, M. P., Leech, D. I., Hatchwell, B. J \& \& Gaston, K. J. (2009) Avian productivity in urban landscapes: a review and meta-analysis. Ibis 151: 1-18. doi: 10.1111/j.1474-919X.2008.00899.x

Chamberlain, D. E., Glue, D. E. \& Toms, M. P. (2009) Sparrowhawk Accipiter nisus presence and winter bird abundance. Journal of Ornithology 150: 247-254. doi: 10.1007/ s10336-008-0344-4

Chiron, F. \& Julliard, R. (2007) Responses of songbirds to magpie reduction in an urban habitat. The Journal of Wildlife Management 71: 2624-2631. doi: 10.2193/2006-105

Clergeau, P. \& Yésou, P. (2006) Behavioural flexibility and numerous potential sources of introduction for the sacred ibis: causes of concern in western Europe? Biological Invasions 8: 1381-1388. doi: 10.1007/s10530-006-0002-9

Clucas, B. \& Marzluff, J. M. (2012) Attitudes and actions toward birds in urban areas: human cultural difference affect bird behavior. The Auk 129: 8-16. doi: 10.1525/auk. 2011.11121

Coffin, A. W. (2007) From roadkill to road ecology: A review of the ecological effects of roads. Journal of Transport Geography 15: 396-406. doi: 10.1016/j.jtrangeo.2006.11.006

Collins, J. P., Kinzig, A., Grimm, N. B., Fagan, W. F., Hope, D., Wu, J. \& Borer, E. T. (2000) A new urban ecology. American Scientist 88: 416-425. doi: 10.1511/2000.5.416

Connell, J. H. (1978) Diversity in tropical rain forests and coral reefs. Science 199: 13021310. doi: $10.1126 /$ science.199.4335.1302

Cowie, R. J. \& Hinsley, S. A. (1988) The provision of food and the use of bird feeders in suburban gardens. Bird Study 35: 163-168. doi: 10.1080/00063658809476985

Croci, S., Butet, A. \& Clergeau, P. (2008) Does urbanization filter birds on the basis of their biological traits. The Condor 110: 223-240. doi: 10.1525/cond.2008.8409

Своокs, K. R. \& Soulé, M. E. (1999) Mesopredator release and avifaunal extinctions in a fragmented system. Nature 400: 563-566. doi: 10.1038/23028 
DAuphiné, N. I. C. O. \& Cooper, R. J. (2009) Impacts of free-ranging domestic cats (Felis catus) on birds in the United States: a review of recent research with conservation and management recommendations. Pp. 205-219. In: Rich, T. D., Arizmendi, C., Demarest, D. W. \& Thompson, C. (eds): Tundra to Tropics. Connecting birds, habitats and people. Vol. 205. Proceedings of the Fourth International Partners in Flight Conference.

Davies, Z. G., Fuller, R. A., Loram, A., Irvine, K. N., Sims, V. \& Gaston, K. J. (2009) A national scale inventory of resource provision for biodiversity within domestic gardens. Biological Conservation 142: 761-771. doi: 10.1016/j.biocon.2008.12.016

Dominoni, D. M., Quetting, M. \& Partecke, J. (2013a) Artificial light at night advances avian reproductive physiology. Proceedings of the Royal Society B: Biological Sciences 280(1756): 20123017. doi: 10.1098/rspb.2012.3017

Dominoni, D. M., Helm, B., Lehmann, M., Dowse, H. B., \& Partecke, J. (2013b) Clocks for the city: circadian differences between forest and city songbirds. Proceedings of the Royal Society B: Biological Sciences 280(1763): 20130593. doi: 10.1098/rspb.2013.0593

Donnelly, R. \& Marzluff, J. M. (2004) Importance of reserve size and landscape context to urban bird conservation. Conservation Biology 18: 733-745. doi: 10.1111/j.15231739.2004.00032.x

Donnelly, R. \& Marzluff, J. M. (2006) Relative importance of habitat quantity, structure, and spatial pattern to birds in urbanizing environments. Urban Ecosystems 9: 99-117. doi: 10.1007/s11252-006-7904-2

Eeva, T. \& Lehikoinen, E. (1996) Growth and mortality of nestling great tits (Parus major) and pied flycatchers (Ficedula hypoleuca) in a heavy metal pollution gradient. Oecologia 108: 631-639. doi: 10.1007/s10646-014-1235-5

Eeva, T. \& LehiKoinen, E. \& RöNKä, M. (1998) Air pollution fades the plumage of the great tit. Functional Ecology 12: 607-612. doi: 10.1046/j.1365-2435.1998.00221.x

Eeva, T., Lehikoinen, E. \& NikinmaA, M. (2003) Pollution-induced nutritional stress in birds: an experimental study of direct and indirect effects. Ecological Applications 13: 1242-1249. doi: 10.1890/01-5375

Eeva, T., Rainio, M., Berglund, Å., Kanevra, M., Stauffer, J., Stöwe, M. \& Ruuskanen, S. (2014) Experimental manipulation of dietary lead levels in great tit nestlings: limited effects on growth, physiology and survival. Ecotoxicology 23(5): 914-928. doi: 10.1007/ s10646-014-1235-5

Eisenbeis, G. \& HÄNEL, A. (2008) Light pollution and the impact of artificial night lighting on insects. Pp. 243-263. In: McDonnell, M. J., Hahs, A. K. \& Breuste, J. H. (eds): Ecology of cities and towns: A comparative approach. Cambridge University Press, New York.

Ericson, P. G. P. (1997) The earliest record of House sparrow (Passer domesticus) in Northern Europe. Journal of Archaeological Science 24: 183-190. doi: 10.1006/jasc.1996.0102

Evans, K. L., Newson, S. E. \& Gaston, K. J. (2009) Habitat influences on urban avian assemblages. Ibis 151: 19-39. doi: 10.1111/j.1474-919X.2008.00898.x

Evans, K. L. (2010) Individual species and urbanization. Pp. 53-87. In: Gaston, K. J. (ed.): Urban ecology. Cambridge University Press, New York. doi: 10.1017/ CBO9780511778483.005

FAETH, S. H., BANG, C. \& SAARI, S. (2011) Urban biodiversity: patterns and mechanisms. Annals of the New York Academy of Sciences 1223: 69-81. doi: 10.1111/j.17496632.2010.05925.x

FierA, C. (2009) Biodiversity of Collembola in urban soils and their use as bioindicators for pollution. Pesquisa Agropecuária Brasileira 44: 868-873. doi: 10.1590/S0100204X2009000800010 
Fischer, J. D., Cleeton, S. H., Lyons, T. P. \& Miller, J. R. (2012) Urbanization and the predation paradox: the role of trophic dynamics in structuring vertebrate communities. Bioscience 62: 809-818. doi: 10.1525/bio.2012.62.9.6

Francis, R. A. \& Chaswick, M. A. (2012) What makes species synurbic? Applied Geography 32: 514-521. doi: 10.1016/j.apgeog.2011.06.013

Fuller, R. A., Warren, P. H. \& Gaston, K. J . (2007) Daytime noise predicts nocturnal singing in urban robins. Biology Letters 3: 368-370. doi: 10.1098/rsbl.2007.0134

Fuller, R. A., Warren, P. H., Armsworth, P. R., Barbosa, O. \& Gaston, K. J. (2008) Garden bird feeding predicts the structure of urban avian assemblages. Diversity and Distributions 14: 131-137. doi: 10.1111/j.1472-4642.2007.00439.x

Gauthreux, S. A. Jr. \& Belser, C. G. (2006) Effects of artificial night lighting on migrating birds. Pp. 67-93. In: Rich, C. \& Longcore, T. (eds): Ecological consequences of artificial night lighting. Island Press, Washington DC.

Gering, J. C. \& Blair, R. B. (1999) Predation on artificial bird nests along an urban gradient: predatory risk or relaxation in urban environments? Ecography 22: 532-541. doi: 10.1111/j.1600-0587.1999.tb00542.x

Giraudeau, M. \& McGraw, K. J. (2014) Physiological correlates of urbanization in a desert songbird. Integrative and Comparative Biology 54(4): 622-332. doi: 10.1093/icb/icu024

Goszczynski, J., JAblonski, P., Leskinski, G. \& Romanowski, J. (1993) Variation in diet of tawny owl Strix aluco L. along an urbanization gradient. Acta Ornithologica 27: 113123.

Grimm, N. B., Faeth, S. H., Golubiewski, N. E., Redman, C. L., Wu, J., Bai, X. \& B riggs, J . M. (2008) Global change and the ecology of cities. Science 319: 756-760. doi: 10.1126/ science.1150195

Gross, K., Pasinelui, G. \& Kunc, H. P . (2010) Behavioral plasticity allows short-term adjustment to a novel environment. American Naturalist 176: 456e464. doi: 10.1086/655428

Grunst, M. L., Rotenberry, J. T. \& Grunst, A. S. (2014) Variation in adrenocortical stress physiology and condition metrics within a heterogeneous urban environment in the song sparrow Melospiza melodia. Journal of Avian Biology 45: 574-583. doi: 10.1111/ jav.00459

Habib, L., Bayne, E. M. \& Boutin, S. (2007) Chronic industrial noise affects pairing success and age structure of ovenbirds Seiurus aurocapilla. Journal of Applied Ecology 44: 176-184. doi: 10.1111/j.1365-2664.2006.01234.x

Halfwerk, W., Hollerman, L. J. M., Lessels, C. M. \& Slabbekoorn, H. (2011) Negative impact of traffic noise on avian reproductive success. Journal of Applied Ecology 48: 210-219. doi: 10.1111/j.1365-2664.2010.01914.x

Harrison, T. J., Smith, J. A., Martin, G. R., Chamberlain, D. E., Bearhop, S., Robb, G. N. \& ReYnolds, S. J. (2010) Does food supplementation really enhance productivity of breeding birds? Oecologia 164: 311-320. doi: 10.1007/s00442-010-1645-x

Haskell, D. G., Knupp, A. M. \& Schneider, M. C. (2001) Nest predator abundance and urbanization. Pp. 243-258. In: Marzluff, J. M., Bowman, R. \& Donnelly, R. (eds): Avian ecology and conservation in an urbanizing world. Kluwer Academic Publishers, Boston. doi: 10.1007/978-1-4615-1531-9_11

НАтсн, J. J. (1996) Threats to public health from gulls (Laridae). International Journal of Environmental Health Research 6: 5-16. doi: 10.1080/09603129609356867

Heiss, R. S., Clark, A. B. \& McGowan, K. J. (2009) Growth and nutritional state of American Crow nestlings vary between urban and rural habitats. Ecological Application 19: 829-839. doi: 10.1890/08-0140.1 
Herr, J., Schley, L . \& Roper, T. J. (2008) Socio-spatial organization of urban stone martens. Journal of Zoology 277: 54-62. doi: 10.1111/j.1469-7998.2008.00510.x

Hofer, C., Gallagher, F. J. \& Holzapfel, C. (2010) Metal accumulation and performance of nestlings of passerine bird species at an urban brownfield site. Environmental Pollution 158: 1207-1213. doi: 10.1016/j.envpol.2010.01.018

Hõrak, P., Vellau, H., Ots, I. \& Møller, A. P. (2000) Growth conditions affect carotenoidbased plumage coloration of great tit nestlings. Naturwissenschaften 87: 460-464. doi: $10.1007 / \mathrm{s} 001140050759$

Hu, Y. \& CARDoso, G. C. (2009) Are bird species that vocalize at higher frequencies preadapted to inhabit noisy urban areas? Behavioral Ecology 20(6): 1268-1273. doi: 10.1093/ beheco/arp131

Janssens, E., Daune, T., Pinxten, R., Bervoets, L., Blust, B. \& Eens, M. (2003) Effects of heavy metal exposure on the condition and health of nestlings of the great tit (Parus major), a small songbird species. Environmental Pollution 126: 267-274. doi: 10.1016/ S0269-7491(03)00185-4

Jones, D. N. \& Reynolds, J. S. (2008) Feeding birds in our towns and cities: a global research opportunity. Journal of Avian Biology 39: 265-271. doi: 10.1111/j.0908-8857.2008.04271.x

JокімӓкI, J. \& Huнта, E. (2000) Artificial nest predation and abundance of breeding birds along an urban gradient. The Condor 102: 838-847. doi: 10.1650/0010-5422(2000)102 [0838:ANPAAO]2.0.CO;2

Kalnay, E. \& CEI, M. (2003) Impact of urbanization and land-use change on climate. Nature 423: 528-531. doi: 10.1038/nature01675

Keeley, W. H. \& Bechard, M. J. (2011) Flushing distances of Ferruginous Hawks nesting in rural and exurban New Mexico. The Journal of Wildlife Management 75: 1034-1039. doi: 10.1002/jwmg.140

KeKKonen, J. (2011) Evolutionary and conservation biology of the Finnish house sparrow. Academic dissertation, University of Helsinki, Finland, $28 \mathrm{pp}$.

Kelcey, J. G. \& Rheinwald, G. (2005) Birds in European cities. Ginster Verlag, St. Katharinen, $450 \mathrm{pp}$.

Kempenaers, B., Borgström, P., Loës, P., Schlicht, E. \& Valcu, M. (2010) Artificial night lighting affects dawn song, extra-pair siring success, and lay date in songbirds. Current Biology 20: 1735-1739. doi: 10.1016/j.cub.2010.08.028

KüBler, S., KupKo, S. \& Zeller, U. (2005) The kestrel (Falco tinnunculus) in Berlin: investigation of breeding biology and feeding ecology. Journal of Ornithology 146: 271-278. doi: 10.1007/s10336-005-0089-2

LACK, D. (1954) The natural regulation of animal numbers. Oxford University Press, London, 343 pp.

Lee, K. N. (2007) An urbanizing world. Pp. 3-21. In: Starke, L. (ed.): State of the World 2007: Our urban future. W.W. Norton \& Company, New York.

Legagneux, P. \& Ducatez, S. (2013) European birds adjust their flight initiation distance to road. Biology Letters 9: 20130417. doi: 10.1098/rsbl.2013.0417

LepczyK, C. A., Mertiga, A. G. \& LiU, J. (2003) Landowners and cat predation across rural-to-urban landscapes. Biological Conservation 115: 191-201. doi: 10.1016/S00063207(03)00107-1

Lepczyk, C. A., Flather, C. H., Radeloff, V. C., Pidgeon, A. M., Hammer, R. B. \& Liu, J. (2008) Human impacts on regional avian diversity and abundance. Conservation Biology 22: 405-416. doi: 10.1111/j.1523-1739.2008.00881.x 
Liker, A., PApp, Z., Bókony, V. \& Lendvai, Á. Z. (2008) Lean birds in the city: body size and condition of House Sparrows along the urbanization gradient. Journal of Animal Ecology 77: 789-795. doi: 10.1111/j.1365-2656.2008.01402.x

Longcore, T. \& Rich, C. (2004) Ecological light pollution. Frontiers in Ecology and the Environment 2: 191-198. doi: 10.1890/1540-9295(2004)002[0191:ELP]2.0.CO;2

Loyd, K. A. T., Hernandeza, S. M., Carrolla, J. P., Kyler, J. A. \& Marshall, G. J . (2013) Quantifying free-roaming domestic cat predation using animal-borne video cameras. Biological Conservation 160: 183-189. doi: 10.1016/j.biocon.2013.01.008

Loss, S. R., Will, T. \& Marra, P. P. (2013) The impact of free-ranging domestic cats on wildlife of the United States. Nature Communications 4: 1396. doi: 10.1038/ncomms2380

Luck, G. W . \& Smallbone, T. W. (2010) Species diversity and urbanisation: patterns, drivers and implications. Pp. 88-119. In: Gaston, K. J. (ed.): Urban ecology. Cambridge University Press, New York. doi: 10.1017/CBO9780511778483.006

MacKenzie, J . A., Hinsley, S. A. \& Harrison, N. M. (2014) Parid foraging choices in urban habitat and their consequences for fitness. Ibis 156: 591-605. doi: 10.1111/ibi.12166

Martin, J. M., French, K., Ross, G. A. \& Major, R. E. (2011) Foraging distances and habitat preferences of a recent urban coloniser: the Australian white ibis. Landscape and Urban Planning 102: 65-72. doi: 10.1016/j.landurbplan.2011.03.010

Marzluff, J. M. (2001) Worldwide urbanization and its effects on birds. Pp. 19-48. In: Marzluff, J. M., Bowman, R. \& Donnelly, R. (eds): Avian ecology and conservation in an urbanizing world. Kluwer Academic Publishers, Boston. doi: 10.1007/978-1-46151531-9_2

Marzluff, J. M., McGowan, K. J., Donnelly, R. \& Knight, R. L. (2001) Causes and consequences of expanding American Crow populations. Pp. 331-363. In: Marzluff, J. M., Bowman, R. \& Donnelly, R. (eds): Avian ecology and conservation in an urbanizing world. Kluwer Academic Publishers, Boston. doi: 10.1007/978-1-4615-1531-9_16

Marzluff, J. M. (2005) Island biogeography for an urbanizing world: how extinction and colonization may determine biological diversity in human-dominated landscapes. Urban Ecosystems 8: 157-177. doi: 10.1007/s11252-005-4378-6

Marzluff, J. M. \& Neatherlin, E. (2006) Corvid response to human settlements and campgrounds: causes, consequences and challenges for conservation. Biological Conservation 130: 301-314. doi: 10.1016/j.biocon.2005.12.026

McInTyre, E. (2013) Ambient noise and the communication of predation risk between parent and nestling tree swallows (Tachyneta bicolor). MsC Thesis, Dalhousie University, Halifax, Nova Scotia, 55 pp.

McKinnEY, M. L. (2002) Urbanization, biodiversity, and conservation. Bioscience 52: 883890. doi: 10.1641/0006-3568(2002)052[0883:UBAC]2.0.CO;2

MCKINNEY, M. L. (2006) Urbanization as a major cause of biotic homogenization. Biological Conservation 127: 247-260. doi: 10.1016/j.biocon.2005.09.005

McKinney, M. L. (2008) Effects of urbanization on species richness: A review of plants and animals. Urban Ecosystems 11: 161-176. doi: 10.1007/s11252-007-0045-4

McIntyre, N. E. \& Rango, J. J. (2009) Arthropods in urban ecosystems: community patterns as functions of anthropogenic land use. Pp. 233-242. In: McDonnell, M. J., Hahs, A. K. \& Breuste, J. H. (eds): Ecology of cities and towns: A comparative approach. Cambridge University Press, New York. doi: 10.1017/CBO9780511609763.015

McLaughlin, K. E. \& Kunc, H. P. (2013) Experimentally increased noise levels change spatial and singing behaviour. Biology Letters 9(1): 20120771 doi: 10.1098/rsbl.2012.0771

Mennechez, G. \& Clergeau, P. (2001) Settlement of breeding European starlings in urban areas: importance of lawns vs. anthropogenic wastes. Pp. 275-287 In: MArzLuff, J. 
M., Bowman, R. \& Donnelly, R. (eds): Avian ecology and conservation in an urbanizing world. Kluwer Academic Publishers, Boston. doi: 10.1007/978-1-4615-1531-9_13

Mennechez, G. \& Clergeau, P. (2006) Effect of urbanisation on habitat generalists: starlings not so flexible? Acta Oecologica 30: 182-191. doi: 10.1016/j.actao.2006.03.002

Miller, J. R., Fraterrigo, J. M., Hobbs, N. T., Theobald, D. M. \& Wiens, J. A. (2001) Urbanization, avian communities, and landscape ecology. Pp. 117-137. In: Marzluff, J., Bowman, R. \& Donnelly, R. (eds): Avian ecology and conservation in an urbanizing world. Kluwer Academic Publishers, Norwell. doi: 10.1007/978-1-4615-1531-9_6

Miller, M. W. (2006) Apparent effects of light pollution on singing behavior of American robins. Condor 108: 130-139. doi: 10.1650/0010-5422(2006)108[0130:AEOLPO]2.0.CO;2

Møller, A. P. (2008) Flight distance of urban birds, predation, and selection for urban life. Behavioral Ecology and Socibiology 63: 63-75. doi: 10.1007/s00265-008-0636-y

Møller, A. P. (2012) Urban areas as refuges from predators and flight distance of prey. Behavioral Ecology 23: 1030-1035. doi: 10.1093/beheco/ars067

Morandini, P . (2006) Budapesti vörös vércse költések. [Breeding events of the kestrel (Falco tinnunculus) in Budapest.] Heliaca 1: 85-87. [in Hungarian]

Nager, R. G., Rübgger, C. \& van Noordwijk, A. J. (1997) Nutrient or energy limitation on egg formation: a feeding experiment in great tits. Journal of Animal Ecology 66(4): 495-507. doi: 10.2307/5944

NeIL, K. \& Wu, J. (2006) Effects of urbanization on plant flowering phenology: A review. Urban Ecosystems 9: 243-257. doi: 10.1007/s11252-006-9354-2

Newton, I. (1986) The Sparrowhawk. T \& AD Poyser Ltd, Calton, 396 pp.

Niemelä, J. \& Kotze, D. J. (2009) Carabid beetle assemblages along urban to rural gradients: A review. Landscape and Urban Planning 92: 65-71. doi: 10.1016/j.landurbplan.2009.05.016

O'Leary, R. \& Jones, D. N. (2006) The use of supplementary foods by Australian magpies Gymnorhina tibicen: Implications for wildlife feeding in suburban environments. Austral Ecology 31: 208-216. doi: 10.1111/j.1442-9993.2006.01583.x

Outridge, P. M. \& Scheuhammer, A. M. (1993) Bioaccumulation and toxicology of chromium: implications for wildlife. Pp. 31-77. In: WARE, G. W. (ed.): Reviews of environmental contamination and toxicology. Springer, New York. doi: 10.1007/978-1-4613-9763-2_2

Parlow, E. (2011) Urban climate. Pp. 31-445. In: Niemela, J. (ed.): Urban ecology -Patterns, processes and applications. Oxford University Press, Oxford. doi: 10.1093/acprof:o so/9780199563562.003.0005

PARris, K. M. \& Schneider, A. (2011) Impacts of traffic noise and traffic volume on birds of roadside habitats. Ecology and Society 14: 29.

Parsons, H., Major, R. E. \& French, K. (2006) Species interactions and habitat associations of birds inhabiting urban areas of Sydney, Australia. Austral Ecology 31: 217-227. doi: 10.1111/j.1442-9993.2006.01584.x

Peach, W. J., Vincent, K. E., Fowler, J. A. \& Grice, P. V. (2008) Reproductive success of house sparrows along an urban gradient. Animal Conservation 11: 493-503. doi: 10.1111/j.1469-1795.2008.00209.x

Peach, W. J., Sheenan, D. K. \& Kirby, W. B. (2014) Supplementary feeding of mealworms enhances reproductive success in garden nesting House Sparrows Passer domesticus. Bird Study 61: 378-385. doi: 10.1080/00063657.2014.918577

Penuelas, J. \& Filella, I. (2001) Responses to a warming world. Science 294: 793-795. doi: 10.1126/science. 1066860

Perrins, C. M. (1965) Population fluctuations and clutch-size in the Great Tit, Parus major L. Journal of Animal Ecology 34: 601-647. doi: 10.2307/2453 
Perry, G. \& Fisher, R. N. (2006) Night lights and reptiles: observed and potential effects. Pp. 169-191. In: Rich, C. \& LongCore, T. (eds): Ecological consequences of artifcial night lighting. Island Press, Washington, DC.

Petren, K. \& Case, T. J . (1996) An experimental demonstration of exploitation competition in an ongoing invasion. Ecology 77: 118-132. doi: 10.2307/2265661

Pickett, S. T. A., Cadenasso, M. L., Grove, J. M., Nilon, C., H., Pouyat, R. V., Zipperer, W. C. \& Constanza, R. (2001) Urban ecological systems: linking terrestrial, ecological, physical, and socioeconomic components of metropolitan areas. Annual Review of Ecology and Systematics 32: 127-157. doi: 10.1146/annurev.ecolsys.32.081501.114012

Pickett, S. T. A., Cadenasso, M. L., Grove, J. M., Boone, C. G., Groffmann, P. M., Irwin, E., Kaushal, S. S., Marshal, V., McGrath, B. P., Nilon, C. H., Pouyat, R. V., Szlávecz, K., Troyl, A . \& Warren, P. (2011) Urban ecological systems: Scientific foundations and a decade of progress. Journal of Environmental Management 92: 331-362. doi: 10.1016/j.jenvman.2010.08.022

Pierotti, R. \& Annett, C. (2001) The ecology of Western gulls in habitats varying in degree of urban influence. Pp. 307-329. In: Marzluff, J. M., Bowman, R. \& Donnelly, R. (eds): Avian ecology and conservation in an urbanizing world. Kluwer Academic Publishers, Boston. doi: 10.1007/978-1-4615-1531-9_15

Plummer, K. E., Bearhop, S., Leech, D. I., Chamberlain, D. E. \& Blount, J. D. (2013a) Fat provisioning in winter impairs egg production during the following spring: a landscape-scale study of blue tits. Journal of Animal Ecology 82: 673-682. doi: 10.1111/13652656.12025

Plummer, K. E., Bearhop, S., Leech, D. I., Chamberlain, D. E. \& Blount, J . D . (2013b) Winter food provisioning reduces future breeding performance in a wild bird. Scientific reports 3. doi: $10.1038 /$ srep02002

Prange, S., Gehrt, S. D . \& Wiggers, E. P. (2003) Demographic factors contributing to high raccoon densities in urban landscapes. Journal of Wildlife Management 67: 324-333. doi: $10.2307 / 3802774$

Quinn, J. L., Whittingham, J. M., Butler, J. S. \& Cresswell, W. (2006) Noise, predation risk compensation and vigilance in the chaffinch Fringilla coelebs. Journal of Avian Biology 37: 601-608. doi: 10.1111/j.2006.0908-8857.03781.x

Ramsay, S. L. \& Houston, D. C. (1997) Nutritional constraints on egg production in the blue tit: a supplementary feeding study. Journal of Animal Ecology 66(5): 649-657. doi: $10.2307 / 5918$

Ramsay, S. L . \& Houston, D. C. (2003) Amino acid composition of some woodland arthropods and its implications for breeding tits and other passerines. Ibis 145: 227-232. doi: 10.1046/j.1474-919X.2003.00133.x

Raupp, M. J., Shrewsbury, P. M. \& Herms, D. A. (2010) Ecology of herbivorous arthropods in urban landscapes. Annual Review of Entomology 55: 19-38. doi: 10.1146/annurevento-112408-085351

Reynolds, S. J., Sсноесн, S. J. \& Bowman, R. (2003) Diet quality during pre-laying and nestling periods influences growth and survival of Florida scrub-jay (Aphelocoma coerulescens) chicks. Journal of Zoology 261: 217-226. doi: 10.1017/S0952836903004023

Richner, H. (1992). The effect of extra food on fitness in breeding carrion crows. Ecology 73 : 330-335. doi: 10.2307/1938744

Risch, M., Dwenger, A. \& Wirth, H. (1996) Der Sperber (Accipiter nisus) als Brutvogel in Hamburg: Bestandsentwicklung und Bruterfolg 1982-1996. Hamburger Avifaunistische Beiträge 28: 43-57. 
Ritchie, E. G. \& Johnson, C. N. (2009) Predator interactions, mesopredator release and biodiversity conservation. Ecology Letters 12: 982-998. doi: 10.1111/j.1461-0248.2009. 01347.x

Rock, P. (2005) Urban gulls: problems and solutions. British Birds 98: 338-355. doi: $10.1890 / 060152$

Robb, G. N., McDonald, R. A., Chamberlain, D. E. \& Bearhop, S. (2008a) Food for thought: supplementary feeding as a driver of ecological change in avian populations. Frontiers in Ecology and the Environment 6: 476-484. doi: 10.1890/060152

Robb, G. N., McDonald, R. A., Chamberlain, D. E., Reynolds, S. J., Harrison, T. J. \& BEARHOP, S. (2008b) Winter feeding of birds increases productivity in the subsequent breeding season. Biology Letters 4: 220-223. doi: 10.1098/rsbl.2007.0622

Rodewald, A. D. \& Shustack, D. P. (2008) Consumer resource matching in urbanizing landscapes: are synanthropic species over-matching. Ecology 89: 515-521. doi: 10.1890/07-0358.1

Rodewald, A. D. \& Kearns, L. J. (2011) Shifts in dominant nest predators along a ruralto-urban landscape gradient. The Condor 113: 899-906. doi: 10.1525/cond.2011.100132

Rodewald, A. D., Kearns, L. J. \& Shustack, D. P. (2011) Anthropogenic resource subsidies decouple predator-prey relationships. Ecological Applications 21: 936-943. doi: 10.1890/10-0863.1

Rodewald, A. D., Kearns, L. J . \& Shustack, D. P. (2013) Consequences of urbanizing landscapes to reproductive performance of birds in remnant forests. Biological Conservation 160: 32-39. doi: 10.1016/j.biocon.2012.12.034

Rogers, C. M. \& Caro, M. J. (1998) Song sparrows, top carnivores and nest predation: a test of the mesopredator release hypothesis. Oecologia 116: 227-233. doi: 10.1007/ s004420050583

Russ, A., RüGer, A . \& Klenke, R. (2014) Seize the night: European Blackbirds (Turdus merula) extend their foraging activity under artificial illumination. Journal of Ornithology 156(1): 123-131. doi: 10.1007/s10336-014-1105-1

Rutz, C. (2008). The establishment of an urban bird population. Journal of Animal Ecology 77: 1008-1019. doi: 10.1111/j.1365-2656.2008.01420.x

Saetre, G. P., Riyahi, S., Aliabadian, M., Hermansen, J. S., Hogner, S., Olsson, U. \& Elgvin, T. O. (2012) Single origin of human commensalism in the house sparrow. Journal of Evolutionary Biology 25: 788-796. doi: 10.1111/j.1420-9101.2012.02470.x

ŠáleK, M., Drahníková, L. \& TKadlec, E. (2015) Changes in home range sizes and population densities of carnivore species along the natural to urban habitat gradient. Mammal Review 45: 1-14. doi: 10.1111/mam.12027

Salvati, L., Manganaro, A., Fattorini, S. \& Piattella, E. (1999) Population features of Kestrels Falco tinnunculus in urban, suburban and rural areas in central Italy. Acta Ornithologica 34: 53-58.

Sauter, A., Bowman, R., Schoech, S. J. \& Pasinelli, G. (2006) Does optimal foraging theory explain why suburban Florida scrub-jays (Aphelocoma coerulescens) feed their young human-provided food? Behavioral Ecology and Sociobiology 60: 465-474. doi: 10.1007/s00265-006-0187-z

Scheuhammer, A. M. (1987) The chronic toxicity of aluminium, cadmium, mercury, and lead in birds: A review. Environmental Pollution 46: 263-295. doi: 10.1016/02697491(87)90173-4

Sсновсн, S. J. (1996) The effect of supplemental food on body condition and the timing of reproduction in a cooperative breeder, the florida scrub-jay. The Condor 98: 234-244. doi: $10.2307 / 1369141$ 
Schroeder, J., Nakagawa, S., Cleasby, I. R. \& Burke, T. (2012) Passerine birds breeding under chronic noise experience reduced fitness. PloS one, 7: e39200. doi: 10.1371/journal.pone.0039200

Schwagmeyer, P. L. \& Mock, D. W. (2008) Parental provisioning and offspring fitness: size matters. Animal Behaviour 75: 291-298. doi: 10.1016/j.anbehav.2007.05.023

Searcy, W. A., Peters, S. \& Nowicki, S. (2004) Effects of early nutrition on growth rate and adult size in song sparrows Melospiza melodia. Journal of Avian Biology 35: 269-279. doi: 10.1111/j.0908-8857.2004.03247.x

Seress, G., Bókony, V., Heszberger, J. \& Liker, A. (2011) Response to predation risk in urban and rural house sparrows. Ethology 117: 896-907. doi: 10.1111/j.14390310.2011.01944.x

Seress, G., Bókony, V., Pipoly, I., Szép, T., Nagy, K. \& Liker, A. (2012) Urbanization, nestling growth and reproductive success in a moderately declining house sparrow population. Journal of Avian Biology 43: 403-414. doi: 10.1111/j.1600-048X.2012.05527.x

Seress, G. (2014) Individual and population level effects of urbanization on house sparrows (Passer domesticus) in Hungary. PhD thesis, University of Pannonia, Veszprém, Hungary. $116 \mathrm{pp}$.

Shawkey, M. D., Bowman, R. \& Woolfenden, G. E. (2004) Why is brood reduction in Florida scrub-jays higher in suburban than in wildland habitats? Canadian Journal of Zoology 82: 1427-1435. doi: 10.1139/z04-123

Shochat, E. (2004) Credit or debit? Resource input changes population dynamics of cityslicker birds. Oikos 106: 622-626. doi: 10.1111/j.0030-1299.2004.13159.x

Shochat, E., Stefanov, W. L., Whitehouse, M. E. A. \& Faeth, S. H. (2004) Urbanization and spider diversity: influences of human modification of habitat structure and productivity. Ecological Applications 14: 268-280. doi: 10.1890/02-5341

Shochat, E., Warren, P. S., Faeth, S. H., McIntyre, N. E. \& Hope, D. (2006) From patterns to emerging processes in mechanistic urban ecology. Trends in Ecology and Evolution 21: 186-191. doi: 10.1016/j.tree.2005.11.019

Shochat, E., Lerman, S. B., Anderies, J. M., Warren, P. S., Faeth, S. H. \& Nilon, C. H. (2010) Invasion, competition, and biodiversity loss in urban ecosystems. BioScience 60: 199-208. doi: 10.1525/bio.2010.60.3.6

Sims, V., Evans, K. L., Newson, S. E., Tratalos, J. A. \& Gaston, K. J. (2008) Avian assemblage structure and domestic cat densities in urban environments. Diversity and Distributions 14: 387-399. doi: 10.1111/j.1472-4642.2007.00444.x

Stabbekoorn, H. \& Peet, M. (2003) Ecology: birds sing at a higher pitch in urban noise. Nature 424: 267-267. doi: 10.1038/424267a

Slabbekoorn, H. \& van Boer-Visser, A. (2006) Cities change the songs of birds. Current Biology 16: 2326-2331. doi: 10.1016/j.cub.2006.10.008

Sodhi, N. S. \& Oliphant, L. W. (1992) Hunting ranges and habitat use and selection of urban-breeding merlins. Condor 94: 743-749. doi: 10.2307/1369259

Sorace, A. (2002) High density of bird and pest species in urban habitats and the role of predator abundance. Ornis Fennica 79: 60-71.

Sorace, A. \& Gustin, M. (2008) Homogenisation processes and local effects on avifaunal composition in Italian towns. Acta Oecologica 33: 15-26. doi: 10.1016/j.actao.2007.07.003

Sorace, A. \& Gustin, M. (2009) Distribution of generalist and specialist predators along urban gradients. Landscape and Urban Planning 90: 111-118. doi: 10.1016/j.landurbplan.2008.10.019 
Stankowich, T. \& Blumstein, B. T. (2005) Fear in animals: a meta-analysis and review of risk assessment. Proceedings of the Royal Society B: Biological Sciences 272: 2627-2634. doi: $10.1098 / \mathrm{rspb} .2005 .3251$

Stracey, C. M. (2011) Resolving the urban nest predator paradox: the role of alternative foods for nest predators. Biological Conservation 144: 1545-1552. doi: 10.1016/j.biocon.2011.01.022

Stracey, C. M. \& Robinson, S. K. (2012). Does nest predation shape urban bird communities? Pp. 49-70. In: LePCZYK, C. A. \& WARREN, P. S. (eds): Urban bird ecology and conservation. Studies in Avian Biology (no. 45). University of California Press, Berkeley. doi: 10.1525/california/9780520273092.003.0004

Sumasgutner, P., Nemeth, E., Tebb, G., Krenn, H. W. \& Gamauf, A. (2014) Hard times in the city-attractive nest sites but insufficient food supply lead to low reproduction rates in a bird of prey. Frontiers in Zoology 11: 48. doi: 10.1186/1742-9994-11-48

Swaileh, K. M. \& Sansur, R. (2006) Monitoring urban heavy metal pollution using the House Sparrow (Passer domesticus). Journal of Environmental Monitoring 8: 209-213. doi: 10.1039/B510635D

Thomas, R. L., Fellowes, M. D. \& Baker, P. J. (2012) Spatio-temporal variation in predation by urban domestic cats (Felis catus) and the acceptability of possible management actions in the UK. PloS one 7(11): e49369. doi: 10.1371/journal.pone.0049369

Tóth, M., BáráNY, A. \& Szenczi, P. (2011) A nyest Budapesten. [The beech marten (Martes foina) in Budapest.] Állattani Közlemények 96: 39-59. [in Hungarian]

UN-Habitat (2012) State of the World's Cities 2010/2011. Cities for All: Bridging the Urban Divide. London, Sterling, VA. 224 pp.

Van Heezik, Y., Smyth, A., Adams, A . \& Gordon, J. (2010) Do domestic cats impose an unsustainable harvest on urban bird populations? Biological Conservation 143: 121-130. doi: 10.1016/j.biocon.2009.09.013

van Nuland, M. E. \& Whitlow, W. L. (2014) Temporal effects on biodiversity and composition of arthropod communities along an urban-rural gradient. Urban Ecosystems 17(4): 1-14. doi: 10.1007/s11252-014-0358-z

van Rensburg, B. J., Peacock, D. S. \& Robertson, M. P. (2009) Biotic homogenization and alien bird species along an urban gradient in South Africa. Landscape and Urban Planning 92: 233-241. doi: 10.1016/j.landurbplan.2009.05.002

Visser, M. E., Holleman L. J. M. \& Gienapp, P. (2006) Shifts in caterpillar biomass phenology due to climate change and its impact on the breeding biology of an insectivorous bird. Oecologia 147: 164-172. doi: 10.1007/s00442-005-0299-6

Warren, P. S., Katti, M., Ermann, M. \& Brazel, A . (2006) Urban bioacoustics: it's not just noise. Animal Behaviour 71: 491-502. doi: 10.1016/j.anbehav.2005.07.014

Wood, W. E. \& Yezerinac, S. M. (2006) Song sparrow (Melospiza melodia) song varies with urban noise. The Auk 123: 650-659. doi: 10.1642/0004-8038(2006)123[650:SSMM SV]2.0.CO;2

Zvereva, E., L. \& Kozlov, M. V. (2010) Responses of terrestrial arthropods to air-pollution: a meta-analysis. Environmental Science and Pollution Research 17: 297-311. doi: 10.1007/ s11356-009-0138-0

Revised version received March 11, 2015, accepted July 20, 2015, published October 19, 2015 